\title{
Genome-Wide Identification of a Large Repertoire of Ralstonia solanacearum Type III Effector Proteins by a New Functional Screen
}

\author{
Takafumi Mukaihara, Naoyuki Tamura, and Masaki Iwabuchi \\ Research Institute for Biological Sciences, Okayama (RIBS), 7549-1 Yoshikawa, Kibichuo-cho, Okayama 716-1241, Japan
}

Submitted 6 October 2009. Accepted 13 November 2009.

\begin{abstract}
The gram-negative plant-pathogenic bacterium Ralstonia solanacearum utilizes the hypersensitive response and pathogenicity (Hrp) type III secretion system (T3SS) to cause disease in plants. To determine the entire repertoire of effector proteins possessed by $R$. solanacearum RS1000, we constructed a transposon carrying a calmodulin-dependent adenylate cyclase reporter that can be used to specifically detect rip (Ralstonia protein injected into plant cells) genes by monitoring the cAMP level in plant leaves inoculated with insertion mutants. From the new functional screen using this transposon, we identified 38 new Rip proteins translocated into plant cells via the Hrp T3SS. In addition, most of the 34 known effectors of RS1000 could be detected by the screen, except for three effectors that appear to be small in size or only weakly expressed. Finally, we identified 72 Rips in RS1000, which include 68 effector proteins classified into over 50 families and four extracellular components of the Hrp T3SS. Interestingly, one-third of the effectors are specific to $R$. solanacearum. Many effector proteins contain various repeated amino acid sequences or known enzyme motifs. We also show that most of the $R$. solanacearum effector proteins, but not Hrp extracellular components, require an Hrp-associated protein, НpaB, for their effective translocation into plant cells.
\end{abstract}

Many gram-negative pathogenic bacteria utilize the type III secretion system (T3SS) to interact with their respective hosts (Cornelis and Van Gijsegem 2000; Mota and Cornelis 2005; Galán and Wolf-Watz 2006). In most gram-negative plantpathogenic bacteria, the virulence-associated T3SS is present and called hypersensitive response and pathogenicity (Hrp) because defects in the T3SS result in the loss of both the ability to induce hypersensitive response (HR) in nonhost plants and pathogenicity in host plants (Alfano and Collmer 1997). The Hrp T3SS acts as a specialized injection system of virulence factors, the so-called effector proteins, into host plant cells. Recent research advances have begun to clarify the role of effector proteins inside host cells; that is, the modification of various plant cellular functions to promote the proliferation of the pathogen (Alfano and Collmer 2004; Mudgett 2005; Jones and Dangl 2006; Gohre and Robatzek 2008).

Corresponding author: T. Mukaihara; Telephone: (+81) 86656 9452; Fax: (+81) 86656 9454; E-mail: mukaihara@bio-ribs.com

Current address of N. Tamura: Agricultural Experimental Station, Okayama Prefectural General Agriculture Center, 1174-1 Koda-Oki, Akaiwa 709-0801, Japan.
As a first step toward understanding how bacterial pathogens manipulate plant cellular functions during infection, it is important to determine the complete repertoire of effector proteins possessed by a certain plant pathogen and to identify the function of individual effectors in host plant cells. For this purpose, attempts to catalog type III effector repertoires in plant-pathogenic bacteria are ongoing. To date, four strategies have mainly been used to identify effector genes. The first strategy is the isolation of pathogenicity-related genes belonging to the $h r p$ regulon. This is based on the finding that the expressions of many type III effector genes from phytopathogenic bacteria are coregulated with those of hrp genes by common regulatory proteins. Such candidate effector genes were isolated by genetic screening (Noël et al. 2001; Fouts et al. 2002; Mukaihara et al. 2004; Chang et al. 2005), by whole-genome computer search for consensus sequences of upstream promoters (Zwiesler-Vollick et al. 2002; Cunnac et al. 2004) or by whole-genome microarray analyses (Occhialini et al. 2005; Ferreira et al. 2006). True effector genes were selected from these candidates by validating their products for the ability to be translocated into plant cells, mainly using a Bordetella pertussis calmodulin-dependent adenylate cyclase (Cya) reporter (Sory and Cornelis 1994; Cunnac et al. 2004; Schechter et al. 2004). By comparing the N-terminal amino acid sequences of effector proteins identified from such studies, several common characteristics of the N-terminal type III secretion signal have been proposed in Pseudomonas syringae pv. tomato DC3000. This gave rise to the second strategy to screen the candidate effector genes; that is, the identification of genes containing probable type III secretion signals (PetnickiOcwieja et al. 2002). The accumulation of information on effector genes in plant- and animal-pathogenic bacteria enabled the development of the third strategy; that is, the isolation of candidate effector genes that show homology to other effector genes. Multiple approaches in combination with the abovementioned strategies enabled the identification of dozens of new effector proteins in genome-sequenced pathogens (Lindeberg et al. 2006; Schechter et al. 2006; Vinatzer et al. 2006; Almeida et al. 2009; Furutani et al. 2009). As the fourth strategy in another line of study, several functional screening systems that can directly identify type III effector genes through an in planta translocation activity of a product have been constructed in $P$. syringae and Xanthomonas campestris. In such systems, effector genes were isolated from random insertions of transposons containing avirulence $(a v r)$ genes lacking the type III secretion signal by monitoring the restoration of Avr-induced HR on plants (Guttman et al. 2002; Roden et al. 2004).

Ralstonia solanacearum is a gram-negative soilborne bacterium that causes bacterial wilt disease in more than 200 plant species, including economically important crops such as tomato, 
potato, tobacco, banana, and eggplant (Hayward 1991). This pathogen enters plant roots, invades xylem vessels, proliferates and spreads throughout the vascular system, and produces a copious amount of extracellular polysaccharides (EPS) that block water transport, resulting in the wilting of infected plants (Schell 2000). As in many other phytopathogenic bacteria, the Hrp T3SS is essential for the growth of $R$. solanacearum in host plants (Boucher et al. 1987). Defects in the Hrp T3SS completely abolish the pathogenicity of the pathogen, whereas mutation in a single effector gene shows little or no effect in most cases (Cunnac et al. 2004; Mukaihara et al. 2004), suggesting that many functionally redundant effector proteins are delivered into plant cells via the Hrp T3SS.

In $R$. solanacearum, expressions of most of the hrp genes and the known effector genes are controlled by an AraC-type transcriptional activator, HrpB (Genin et al. 1992). In a previous study, using a genetic screen, we identified 30 hpx ( $h r p B$ dependent expression) genes and well-known popA, popB, and pop $C$ genes as candidate effector genes in $R$. solanacearum RS1000 (Mukaihara et al. 2004). Recently, we have cloned 11 additional candidate effector genes that share homology with known $h p x$ genes from RS1000. Using a Cya reporter system, we investigated the translocation of these 44 gene products

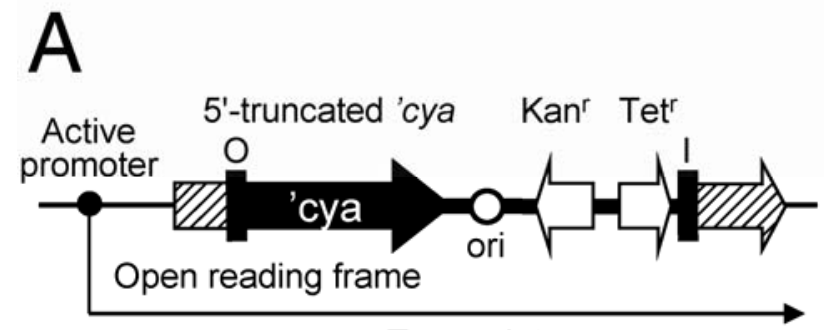

Transcript

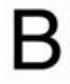

CAMP (fmol/well)

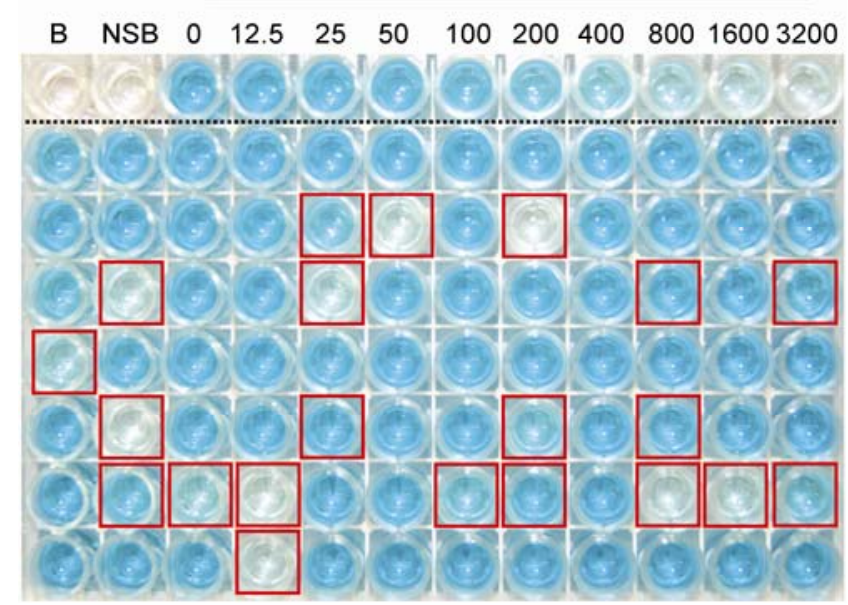

Fig. 1. Calmodulin-dependent adenylate cyclase (Cya)-based functional screen for genes encoding proteins translocated into plant cells. A, Structure of mini-Tn $5^{\prime} c y a$ transposon. The filled boxes indicate inner (I) and outer (O) ends of IS50, and the thick line between them indicates a transposon sequence. The 5'-truncated 'cya gene is represented by a filled arrow. Open arrows represent antibiotic-resistant genes. An open circle represents the origin (ori) of pMB1 used for plasmid rescue. The thin line shows the genome of Ralstonia solanacearum. A hatched box represents an open reading frame. $\mathbf{B}$, Monitoring of the cAMP levels of plant samples inoculated with a pool of 96 insertion mutants. Numbers on the top wells indicate the concentration of cAMP standards (0 to 3,200 fmol/). B and NSB indicate blank and nonspecific binding, respectively. Wells that show an increased cAMP level (more than $50 \mathrm{fmol} /$ well) are boxed in red. into plant cells via the Hrp T3SS, and identified 34 effector genes (Mukaihara and Tamura 2009). However, a large number of potential effector genes are considered to still exist in $R$. solanacearum because our search for $h r p B$-regulated genes is not saturated (Mukaihara et al. 2004) and because a genomewide microarray analysis identified $143 \mathrm{hrpB}$ upregulated genes in $R$. solanacearum GMI1000 (Occhialini et al. 2005). The genome sequence of RS1000 has not yet been analyzed; hence, we could not apply any bioinformatics- or microarraybased prediction of candidate effector genes, as performed in the two genome-sequenced strains GMI1000 (Salanoubat et al. 2002) and UW551 (Gabriel et al. 2006), to this strain. The objective of this study was to construct a new functional screening system that can detect type III effector genes at the genomewide level even in a genome-unsequenced strain.

In a Cya reporter assay on plants, the translocation of effector proteins into plant cells was clearly detected on the basis of the Cya activity as a high production of cAMP, which increased 100- to 10,000-fold compared with the background level, even though the expression levels of effector proteins were low (Mukaihara and Tamura 2009). This is caused by the very low concentration of cAMP in higher plant tissues compared with animal tissues (Spiteri et al. 1989). Such a high sensitivity of the Cya reporter in plant systems led us to the idea of using a Cya reporter instead of an Avr reporter for the functional screening of effector genes. In this study, we constructed a transposon containing a 'cya gene for searching $R$. solanacearum genes containing an in planta translocation signal. Using the new screening system, we identified a large repertoire of type III effector proteins translocated into plant cells via the Hrp T3SS. We also show that most of the $R$. solanacearum effector proteins require an Hrp-associated protein, $\mathrm{HpaB}$, for their effective translocation into plant cells.

\section{RESULTS}

\section{A functional screen to isolate $\boldsymbol{R}$. solanacearum genes encoding proteins translocated into plant cells.}

Using the plasmid pTNP106, we constructed a library of mini-Tn5'cya insertions in $R$. solanacearum $\mathrm{RS} 1085$, a nalidixic acid-resistant $\left(\mathrm{Nal}^{\mathrm{r}}\right) \mathrm{EPS}^{-}$derivative of the wild-type strain RS1000. RS1085 is deficient in the production of EPS and, therefore, can form more than 100 single colonies on a selective plate. The transposon mini-Tn $5^{\prime}$ cya contains an N-terminal-truncated 'cya gene associated with the $\mathrm{O}$-end and the kanamycinresistant gene $\left(\operatorname{Kan}^{\mathrm{r}}\right)$ for the selection of insertion mutants (Fig. 1A). When mini-Tn $5^{\prime} c y a$ is transposed into the genome of RS1085 from pTNP106 and inserted in frame into an open reading frame (ORF) under the control of an active promoter, the insertion mutant can express a Cya fusion protein. Mutants expressing a Cya fusion protein translocated into plant cells were screened by the following plant assay. First, cultures of a set of 96 insertion mutants were combined as a pool, and the mixture was inoculated into a host eggplant leaf. Then, leaf disks were taken from the leaf $15 \mathrm{~h}$ after inoculation, and the cAMP level in the sample was measured. In all, 8,064 insertion mutants were assayed as 84 pools, and several pools showed a marked increase in the cAMP level (more than $50 \mathrm{fmol} /$ well) in the inoculated leaves compared with other samples (Fig. 1B). These pools (boxed in red) were isolated as positive pools because they were considered to contain a positive mutant expressing a Cya fusion protein translocated into plant cells. Next, the 96 mutants in a positive pool were divided into several minigroups and the plant assay was repeated until a single positive mutant was specified in the pool. In this study, we assayed approximately 105,000 insertion mutants as 1,092 pools on eggplant leaves and finally isolated 314 positive mutants. 


\section{Identification of rip genes.}

Each of the genomic DNAs from the 314 positive mutants was purified and the DNA region surrounding the transposon was rescued as described in Materials and Methods. Sequence analysis revealed that 308 of these mutants were independent insertions. These mutants were designated A1 to A308. Of these, 186 transposons were inserted into known hpx and pop genes for which the translocations of their protein products into plant cells have been demonstrated. To date, we have reported 34 type III effector proteins encoded by the $h p x$ and pop genes in $R$. solanacearum RS1000 (Mukaihara and Tamura 2009). In this study, 31 of them were detected by the screen (Table 1), indicating that our new functional screening system can efficiently trap type III effector genes. The other 122 transposons were inserted into new loci, and 38 new genes were identified (Table 2). These genes were designated rip (Ralstonia protein injected into plant cells), associated with the first designation of effector genes in $R$. solanacearum (Cunnac et al. 2004). The above $34 h p x$ and pop genes were simultaneously renamed using the designation of rip (Table 1). Most of the rip genes were trapped by more than two independent transposon insertions (Tables 1 and 2), indicating that our screen for rip genes reached a near-saturation level.

\section{hrpB-dependent expression of new rip genes.}

Sequence analysis revealed that most of the 38 newly identified rip genes contained a perfect or imperfect plant-inducible promoter (PIP) box motif (consensus 5'-TTCGB-N 15 -TTCGB$\left.3^{\prime}\right)$, a recognition sequence by the $\mathrm{HrpB}$ transcriptional activator, on the putative promoter region (Table 3). To examine whether these genes are actually regulated by $\mathrm{HrpB}$, we compared the expression level of the Cya fusion protein between the $h r p B^{c}$ (constitutively expressing $h r p B$ ) and $\triangle h r p B$ strains. The Cya activities of 31 rip genes, which have a PIP box motif in the putative promoter region, increased 4- to 80-fold in the $h r p B^{c}$ background compared with the $\Delta h r p B$ background (Table 3 ). In five rip genes (namely, rip3, rip7, rip22, rip69, and rip70), which have a disrupted or no PIP box motif, the Cya activities were similar in both $h r p B^{c}$ and $\Delta h r p B$ backgrounds but the expression levels were very low. Two rip genes (namely, rip4 and rip72), showed the hrpB-dependent expression of the Cya fusion whereas no PIP box motif was found in the upstream region of these genes. These results indicated that the expressions of most of the new rip genes were regulated by HrpB.

\section{The new rip gene products were translocated into plant cells in an Hrp-T3SS-dependent manner.}

To examine whether the new rip gene products were translocated into plant cells via the Hrp T3SS, we constructed $\Delta h r p Y$ strains expressing the Cya fusion protein. The $h r p Y$ gene encodes an Hrp pilin protein, HrpY (Van Gijsegem et al. 2000). In the $\Delta h r p Y$ mutant, $h r p B$ is still active but functional Hrp complexes are not produced. The $h r p^{+}$and $\Delta h r p Y$ strains were inoculated into host eggplant leaves, and the cAMP level in the inoculated leaves was measured $12 \mathrm{~h}$ after inoculation. Interestingly, in all of the 38 new rip genes, the cAMP level did not increase in the $\Delta h r p Y$ background although it increased 100- to 4,600-fold in the $h r p^{+}$background compared with the

Table 1. Detection of 34 known type III effector genes in Ralstonia solanacearum RS1000

\begin{tabular}{|c|c|c|c|}
\hline Gene & mini-Tn5'cya fusion $^{a}$ & $\begin{array}{l}\text { Protein size } \\
\text { (aa) }\end{array}$ & $\begin{array}{l}\text { Insertion } \\
\text { site }(\mathbf{a a})^{\mathbf{b}}\end{array}$ \\
\hline hpx2 (rip50) & A6*, A83 & 481 & 227 \\
\hline hpx4 (rip45) & A7, A8, A45, A49, A89, A97, A99, A117, A151, A190, A192*, A196, A226, A261, A286, A289, A301 & 1,335 & 281 \\
\hline hpx8 (rip68) & $\mathrm{A} 130 *, \mathrm{~A} 237$ & 228 & 53 \\
\hline hpx9 (rip66) & A126, A193* & 878 & 350 \\
\hline hpx10 (rip56) & $\begin{array}{l}\text { A4, A11, A28, A56, A72, A78, A93, A119, A129, A148*, A183, A201, A202, A221, A239, A241, } \\
\text { A243, A277, A298 }\end{array}$ & 1,156 & 113 \\
\hline hpx11 (rip2) & $\mathrm{A} 173, \mathrm{~A} 250 *$ & 455 & 117 \\
\hline hpx13 (rip13) & A62, A86*, A162, A240, A283 & 621 & 145 \\
\hline hpx14 (rip14) & $\mathrm{A} 10, \mathrm{~A} 85^{*}, \mathrm{~A} 145, \mathrm{~A} 267$ & 647 & 85 \\
\hline hpx15 (rip17) & A $209 *$, A 260 & 462 & 168 \\
\hline hpx16 (rip18) & Not detected & 538 & $\ldots$ \\
\hline hpx17 (rip19) & $\mathrm{A} 58, \mathrm{~A} 276^{*}$ & 720 & 607 \\
\hline hpx18 (rip21) & $\mathrm{A} 214 *$ & 306 & 204 \\
\hline hpx20 (rip37) & A16, A27, A37, A44, A55*, A115, A137, A271 & 1,035 & 192 \\
\hline hpx21 (rip55) & A91*, A144, A197, A207, A227, A278 & 411 & 87 \\
\hline hpx23 (rip63) & $\mathrm{A} 77, \mathrm{~A} 292 *$ & 518 & 188 \\
\hline hpx24 (rip64) & A59*, A293 & 1,702 & 1,518 \\
\hline hpx25 (rip34) & A36*, A131, A188, A254, A264, A265, A281, A295 & 641 & 43 \\
\hline hpx26 (rip58) & $\mathrm{A} 138^{*}, \mathrm{~A} 255$ & 474 & 162 \\
\hline hpx27 (rip39) & $\mathrm{A} 165^{*}, \mathrm{~A} 172, \mathrm{~A} 218, \mathrm{~A} 231$ & 830 & 98 \\
\hline hpx28 (rip23) & A19*, A153, A156, A175, A242 & 809 & 685 \\
\hline hpx29 (rip12) & $\mathrm{A} 48, \mathrm{~A} 90, \mathrm{~A} 163, \mathrm{~A} 206^{*}, \mathrm{~A} 225$ & 514 & 242 \\
\hline hpx30 (rip20) & A17, A43, A71, A98*, A102, A133, A135, A154, A208, A217, A236, A245, A248, A304 & 2,497 & 239 \\
\hline hpx31 (rip29) & A32, A51, A73, A118, A120, A182, A186, A194, A238*, A270 & 1,127 & 105 \\
\hline hpx32 (rip44) & $\mathrm{A} 140 *, \mathrm{~A} 251$ & 1,238 & 542 \\
\hline hpx33 (rip43) & A23, A81, A101, A109, A110, A149, A152, A155*, A203, A259 & 1,375 & 144 \\
\hline hpx34 (rip33) & $\mathrm{A} 31, \mathrm{~A} 57, \mathrm{~A} 124, \mathrm{~A} 204 *, \mathrm{~A} 220$ & 2,339 & 443 \\
\hline hpx35 (rip54) & $\mathrm{A} 30, \mathrm{~A} 50, \mathrm{~A} 79^{*}, \mathrm{~A} 112, \mathrm{~A} 249, \mathrm{~A} 262$ & 2,208 & 1,168 \\
\hline hpx36 (rip65) & A96, A123, A146, A167, A198, A288*, A300 & 2,504 & 743 \\
\hline hpx37 (rip27) & $\begin{array}{l}\text { A13, A34, A41, A61, A65, A74, A82, A84, A113, A116*, A127, A132, A147, A158, A168, A170, } \\
\text { A174, A181, A199, A212, A223, A244, A246, A299, A307 }\end{array}$ & 2,353 & 331 \\
\hline рорА (rip49) & A274* & 330 & 282 \\
\hline popB (rip48) & Not detected & 174 & $\ldots$ \\
\hline popC (rip47) & $\mathrm{A} 53 *, \mathrm{~A} 215, \mathrm{~A} 272, \mathrm{~A} 287$ & 984 & 198 \\
\hline gala1 (rip53) & Not detected & 493 & $\ldots$ \\
\hline gala3 (rip28) & A63*, A296 & 607 & 450 \\
\hline
\end{tabular}

\footnotetext{
${ }^{\text {a }}$ Smallest fusion in the multiple isolates is indicated by an asterisk.

b Number of amino acids from strat codon to insertion site of transposon in smallest fusion.
} 
background level (Table 4). This result clearly indicates that all 38 rip gene products were translocated into plant cells via the Hrp T3SS. Adding the 38 Rips to the 34 previously identified Rips (Mukaihara and Tamura 2009), strain RS1000 was found to possess at least 72 Rips as Hrp T3SS substrate proteins (Table 5). It has been shown that the type III secretion signal is located within the first 50 to $100 \mathrm{~N}$-terminal amino acids of the effector protein. All of the Tn insertion mutants isolated in this study showed a fusion of the Cya reporter after the first 41 $\mathrm{N}$-terminal amino acids of the protein (Tables 1 and 2).

\section{Sequence features of new Rip proteins.}

The sequences of the 38 newly identified Rip proteins were compared with published sequences on databases (Table 5). All of the known $R$. solanacearum Hrp-secreted type III effector proteins that have been reported to date but have not yet been identified from RS1000-namely, AvrA (Meyer et al. 2006), PopP1 (Lavie et al. 2002), PopP2 (Deslandes et al. 2003), and RipT (Cunnac et al. 2004)—were detected using the screen. This result also supports the abovementioned conclusion that the identification of RS1000 rip genes is nearly saturated in this screen. Eight of the new Rips (namely, Rip24, Rip26, Rip30, Rip32, Rip35, Rip36, Rip40, and Rip62) were found to share homology with known type III effector proteins from other plant-pathogenic bacteria, designated Hrp outer protein (Hop) from $P$. syringae and Xanthomonas outer protein
(Xop) from Xanthomonas spp. Interestingly, several Rips contained eukaryotic protein motifs, such as ankyrin repeats (Rip1, Rip3, and Rip60), Ser/Thr acetyltransferase (Rip4, Rip7, Rip8, and Rip9), Ser/Thr kinase (Rip60), and pentatricopeptide (PPR) repeats (Rip31). Rip38 shared homology with class III lipase. Four Rips (namely, Rip24, Rip46, Rip52, and Rip70) were considered to be extracellular components of the Hrp secretion apparatus because they are homologues of the HrpW harpin from $P$. syringae and Erwinia amylovora (Charkowski et al. 1998; Kim and Beer 1998), the Hrp pilin protein HrpY (Van Gijsegem et al. 2000), and the translocon proteins PopF1 and PopF2 (Meyer et al. 2006), respectively.

\section{Most $\boldsymbol{R}$. solanacearum type III effector proteins required Hrp-associated protein $\mathrm{HpaB}$ \\ for effective translocation into plant cells.}

In a previous study, we identified an $h r p B$-regulated gene, $h p a B$, in the $h r p$ cluster (Mukaihara et al. 2004). The hpaBdefective mutants of $R$. solanacearum showed a typical Hrpdeficient phenotype, the loss of HR induction and pathogenicity in plants, although Hrp pili were still produced on the cell surface of the mutant. Therefore, we considered that defects in $h p a B$ may affect the translocation of effector proteins into plant cells via the Hrp T3SS. To verify this hypothesis by in planta Cya activity assay, we examined the translocation of the 72 abovementioned Rip proteins into plant cells in the $\Delta h p a B$

Table 2. Thirty-eight newly isolated rip (Ralstonia protein injected into plant cells) genes in this study

\begin{tabular}{|c|c|c|c|c|}
\hline Gene & DDBJ accession no. ${ }^{a}$ & $\operatorname{mini}^{-T n} 5^{\prime} c y a$ fusion ${ }^{b}$ & $\begin{array}{l}\text { Protein size } \\
\text { (aa) }\end{array}$ & $\begin{array}{c}\text { Insertion site } \\
(\text { aa) }\end{array}$ \\
\hline ripl & AB516324 & A200*, A269 & 430 & 118 \\
\hline rip3 & AB516325 & $\mathrm{A} 40 *$ & 162 & 67 \\
\hline rip4 & AB516326 & A38, A134, A166*, A169, A177, A294 & 311 & 169 \\
\hline $\operatorname{rip} 5(\operatorname{avr} A)$ & AB302266 & $\mathrm{A} 150 *$ & 267 & 219 \\
\hline rip6 & AB516327 & $\mathrm{A} 256^{*}$ & 98 & 67 \\
\hline rip7 (popP1) & AB302267 & $\mathrm{A} 69^{*}, \mathrm{~A} 143$ & 368 & 215 \\
\hline rip8 (рорР2-1) & AB302268 & A 20, A $39 *, A 105$, A 176, A228, A282 & 488 & 55 \\
\hline rip9 (рорР2-2) & AB516328 & A191* & 240 & 86 \\
\hline rip10 & AB516329 & $\mathrm{A} 1 *$ & 157 & 132 \\
\hline rip11 & AB516330 & $\mathrm{A} 2 *, \mathrm{~A} 5$ & 96 & 49 \\
\hline rip15 & AB516331 & A24, A26, A29, A35, A52, A68, A76*, A103, A161, A235, A308 & 765 & 53 \\
\hline rip16 & AB516332 & $\mathrm{A} 70, \mathrm{~A} 114 *, \mathrm{~A} 159, \mathrm{~A} 224, \mathrm{~A} 285$ & 584 & 89 \\
\hline rip22 & AB5 16348 & $\mathrm{~A} 189 *$ & 188 & 175 \\
\hline rip24 & $\mathrm{AB} 302275$ & A279* & 380 & 372 \\
\hline rip25 (ripT) & AB302269 & $\mathrm{A} 75^{*}, \mathrm{~A} 266$ & 297 & 41 \\
\hline rip26 & AB302270 & A9, A14, A15, A21*, A66, A80, A88, A95, A108, A210, A229, A273 & 425 & 99 \\
\hline rip30 & AB516333 & $\mathrm{A} 64^{*}, \mathrm{~A} 252$ & 719 & 530 \\
\hline rip31 & AB516334 & $\mathrm{A} 33, \mathrm{~A} 222 *, \mathrm{~A} 302$ & 1,336 & 632 \\
\hline rip32 & AB516335 & $\mathrm{A} 106, \mathrm{~A} 141 *, \mathrm{~A} 219, \mathrm{~A} 290$ & 742 & 50 \\
\hline rip35 & AB302272 & $\mathrm{A} 128, \mathrm{~A} 284 *$ & 451 & 372 \\
\hline rip36 & AB302273 & A $216^{*}$, A 305 & 218 & 165 \\
\hline rip38 & AB516336 & $\mathrm{A} 42 *, \mathrm{~A} 100, \mathrm{~A} 185, \mathrm{~A} 232$ & 449 & 102 \\
\hline rip40 & AB302271 & $\mathrm{A} 12, \mathrm{~A} 22^{*}, \mathrm{~A} 25, \mathrm{~A} 87, \mathrm{~A} 136, \mathrm{~A} 213, \mathrm{~A} 253$ & 292 & 59 \\
\hline rip41 & AB5 16337 & $\mathrm{~A} 160, \mathrm{~A} 233 *, \mathrm{~A} 263$ & 203 & 79 \\
\hline rip42 & AB516337 & A $184 *$ & 189 & 168 \\
\hline rip46 (hpaZ) & $\mathrm{AB} 167955$ & $\mathrm{~A} 47^{*}, \mathrm{~A} 230$ & 75 & 49 \\
\hline rip51 & AB516338 & A46, A111, A179*, A180, A291 & 659 & 281 \\
\hline rip52 (popF2) & AB516339 & $\mathrm{A} 60, \mathrm{~A} 122, \mathrm{~A} 187^{*}, \mathrm{~A} 247$ & 740 & 203 \\
\hline rip57 & AB516340 & A94, A121, A164*, A205, A 275 & 1,364 & 102 \\
\hline rip59 & AB516341 & $\mathrm{A} 107, \mathrm{~A} 268 *$ & 292 & 180 \\
\hline rip60 & AB5 16342 & $\mathrm{~A} 18^{*}, \mathrm{~A} 54, \mathrm{~A} 125, \mathrm{~A} 142, \mathrm{~A} 171, \mathrm{~A} 178, \mathrm{~A} 258$ & 763 & 119 \\
\hline rip61 & AB516343 & A $104 *$, A 211, A 257 & 605 & 100 \\
\hline rip62 & AB302274 & A67, A157* & 822 & 419 \\
\hline rip67 & AB516349 & $\mathrm{A} 195^{*}, \mathrm{~A} 306$ & 197 & 121 \\
\hline rip69 & AB516344 & A 280, A $303 *$ & 448 & 323 \\
\hline rip70 ( popF1) & AB516345 & $\mathrm{A} 234^{*}$ & 726 & 702 \\
\hline rip71 & AB516346 & A $139 *$, A297 & 255 & 163 \\
\hline rip72 & AB5 16347 & A3*, A92 & 325 & 92 \\
\hline
\end{tabular}

${ }^{\mathrm{a}}$ DDBJ = DNA Data Bank of Japan.

${ }^{\mathrm{b}}$ Smallest fusion in the multiple isolates is indicated by an asterisk.

${ }^{\mathrm{c}}$ Number of amino acids from strat codon to insertion site of transposon in smallest fusion. 
background. In 66 Rip proteins, the cAMP level in inoculated leaves markedly decreased in the $\triangle h p a B$ mutants (Table 4). In contrast, in the remaining six Rips-namely, Rip24, Rip46 (HpaZ), Rip48 (PopB), Rip49 (PopA), Rip52 (PopF2), and Rip70 (PopF1) - cAMP level even increased three to 23-fold in the $\triangle h p a B$ mutants (Table 4). This result indicates that most of the $R$. solanacearum effector proteins require $\mathrm{HpaB}$ for their effective translocation into plant cells via the Hrp T3SS.

\section{Comparison of repertoire of Rip proteins among $R$. solanacearum strains.}

We compared amino acid sequences of the 72 Rip proteins from RS1000 (race 1, biovar, 4 phylotype I) with those from two genome-sequenced strains GMI1000 (race 1, biovar 3, phylotype I) and UW551 (race 3, biovar 2, phylotype II). Most of the Rip proteins from RS1000 showed more than 95\% identity to those from GMI1000 but much lower similarities to those from UW551 (Table 5). The surrounding genes of most of the rip genes showed the same gene order as those of GMI1000 within the sequenced range (data not shown). These results indicate that the two phylotype I strains RS1000 and GMI1000 are closely related at the DNA level. Despite the high similarity to
GMI1000, several effector genes of RS1000 showed mutations, such as hyperaccumulation of point mutation (ripl3), frame shift (rip4, rip9, and rip71), deletion (rip3, rip5, rip19, and rip53), and insertion of an insertion element (IS) sequence (rip12, rip22, rip60, and rip67). On the other hand, rip60 in GMI1000 was disrupted by IS insertion. Genes rip38 and rip59 were not found in the genome of GMI1000 but existed in that of UW551. Gene rip38 was located between RSp0720 and RSp0721 on the genome of RS1000, and the gene order is conserved in UW551 (data not shown). This may indicate that rip38 is deleted in the genome of GMI1000. Gene rip59 was replaced with another gene, RSp1212, in the genome of GMI1000 (data not shown). Interestingly, RSp1212 was an $h r p B$-regulated gene containing a PIP-box promoter and predicted to encode a type III effector protein in GMI1000 (Occhialini et al. 2005). Gene rip10 was not found in the genome of GMI1000 or UW551 and was considered to be specific in RS1000.

\section{DISCUSSION}

In this study, using a Cya reporter instead of an Avr reporter, we constructed a new functional screening system to isolate

Table 3. In vitro adenylate cyclase activity of cell lysates from Ralstonia solanacearum hrpB ${ }^{\mathrm{c}}$ and $\Delta$ hrpB strains containing 'cya fusion in new rip (Ralstonia protein injected into plant cells) genes

\begin{tabular}{|c|c|c|c|c|c|c|c|}
\hline \multirow[b]{2}{*}{ Gene } & \multicolumn{2}{|c|}{ Probable PIP box and -10 sequence ${ }^{a}$} & \multirow[b]{2}{*}{ 'cya fusion } & \multicolumn{2}{|c|}{ cAMP level $^{\text {b }}$} & \multirow[b]{2}{*}{$h r p B^{c} / \Delta h r p B$} & \multirow[b]{2}{*}{ Expressed $^{\mathrm{C}}$} \\
\hline & Position & Nucleotide sequence & & $\operatorname{hrpB}^{\mathbf{c}}$ & $\Delta h r p B$ & & \\
\hline ripl & -100 & TTCGT-N16-TTCGC-N30-GAGTCT & A269 & $10.5 \pm 3.94$ & $0.12 \pm 0.04$ & 87.5 & Yes \\
\hline rip3 & $\ldots$ & Not found & A40 & $0.08 \pm 0.01$ & $0.07 \pm 0.02$ & 1.1 & No \\
\hline rip4 & $\ldots$ & Not found & A134 & $1.90 \pm 0.46$ & $0.08 \pm 0.04$ & 23.8 & Yes \\
\hline rip5 & -97 & TTCGC-N15-TTCGC-N31-AATACT & A150 & $26.6 \pm 3.92$ & $0.09 \pm 0.01$ & 296 & Yes \\
\hline rip6 & -557 & TTCGG-N15-TTCGG-N32-TATTTT & $\mathrm{A} 256$ & $0.32 \pm 0.04$ & $0.06 \pm 0.01$ & 5.3 & Yes \\
\hline rip7 & $\ldots$ & IS insertion in the PIP box motif & A69 & $0.18 \pm 0.02$ & $0.14 \pm 0.01$ & 1.3 & No \\
\hline rip8 & -152 & TTCGG-N15-TTCGC-N31-TAAGCT & A176 & $120 \pm 23.9$ & $6.45 \pm 0.78$ & 18.6 & Yes \\
\hline rip9 & -302 & TTCGG-N15-TTCGC-N31-TATTGT & A191 & $27.5 \pm 5.02$ & $0.20 \pm 0.05$ & 138 & Yes \\
\hline rip10 & -238 & TTCGC-N15-TTCGC-N31-TAAGCT & A 1 & $60.4 \pm 12.2$ & $0.22 \pm 0.04$ & 275 & Yes \\
\hline rip11 & -87 & TTCGC-N15-TTCGC-N30-AACAAT & A2 & $78.6 \pm 6.83$ & $0.18 \pm 0.05$ & 437 & Yes \\
\hline rip15 & -182 & TACGC-N15-TTCGC-N31-CACAGT & A24 & $0.84 \pm 0.08$ & $0.07 \pm 0.02$ & 12.0 & Yes \\
\hline rip16 & -597 & TTCGC-N15-TTCGC-N31-TATGGT & $\mathrm{A} 224$ & $38.4 \pm 6.72$ & $0.10 \pm 0.02$ & 384 & Yes \\
\hline rip22 & $\ldots$ & Not found & A189 & $0.25 \pm 0.12$ & $0.15 \pm 0.05$ & 1.7 & No \\
\hline rip24 & -123 & TTCGT-N15-TGCGG-N32-TACAAC & A279 & $750 \pm 139$ & $4.37 \pm 0.76$ & 172 & Yes \\
\hline rip25 & -161 & TTCGT-N15-TTCGG-N32-TACGCT & A75 & $8.17 \pm 1.61$ & $0.11 \pm 0.02$ & 74.3 & Yes \\
\hline rip26 & -127 & TTCGC-N15-TTCGC-N31-TATGCT & A 15 & $131 \pm 21.9$ & $2.24 \pm 0.44$ & 58.5 & Yes \\
\hline rip30 & -173 & TTCGC-N15-TTCGC-N31-CATAGT & A64 & $4.64 \pm 1.76$ & $0.13 \pm 0.03$ & 35.7 & Yes \\
\hline rip31 & -177 & ATCGC-N15-TTCGC-N31-TATAAA & A33 & $2.39 \pm 1.09$ & $0.20 \pm 0.08$ & 12.0 & Yes \\
\hline rip32 & -239 & TTCGC-N15-TTCGC-N32-CATACT & A106 & $0.92 \pm 0.07$ & $0.11 \pm 0.03$ & 8.4 & Yes \\
\hline rip35 & -251 & TTCGC-N15-TTCGC-N31-TATCGT & A128 & $63.6 \pm 14.6$ & $0.81 \pm 0.05$ & 78.5 & Yes \\
\hline rip36 & -126 & TTCGC-N15-TTCGC-N31-TAGCAT & A216 & $37.9 \pm 7.60$ & $0.21 \pm 0.02$ & 180 & Yes \\
\hline rip38 & -142 & TTCGC-N15-TTCGT-N32-TAGATT & A185 & $2.94 \pm 1.15$ & $0.18 \pm 0.05$ & 16.3 & Yes \\
\hline rip40 & -305 & TTCGC-N15-TTCGC-N34-CAATCT & A 25 & $3.75 \pm 0.68$ & $0.04 \pm 0.01$ & 93.8 & Yes \\
\hline rip41 & $-1,126$ & TTCGG-N15-TTCGC-N31-TAGGAT & A160 & $0.70 \pm 0.04$ & $0.09 \pm 0.03$ & 7.8 & Yes \\
\hline rip42 & -92 & TTCGG-N15-TTCGC-N31-TAGGAT & A184 & $84.8 \pm 31.5$ & $0.28 \pm 0.06$ & 303 & Yes \\
\hline rip46 & -627 & TTCGT-N15-TTCGG-N32-CATCAT & $\mathrm{A} 230$ & $568 \pm 135$ & $0.23 \pm 0.04$ & 247 & Yes \\
\hline rip51 & -104 & TTCGC-N15-TTCGC-N32-CATGCT & A111 & $10.3 \pm 5.06$ & $0.14 \pm 0.06$ & 73.6 & Yes \\
\hline rip52 & -114 & TTCGC-N15-TTCGC-N32-TAGCCT & A122 & $6.85 \pm 2.25$ & $0.28 \pm 0.10$ & 24.5 & Yes \\
\hline rip57 & -94 & TTCGC-N15-TTCGC-N32-TAGCCT & A94 & $2.26 \pm 1.00$ & $0.16 \pm 0.04$ & 14.1 & Yes \\
\hline rip59 & -135 & TTCGT-N15-TTCGG-N32-TACGGT & A268 & $1.65 \pm 0.48$ & $0.14 \pm 0.05$ & 11.8 & Yes \\
\hline rip60 & -178 & TTCGG-N15-TTCGG-N31-TACCGT & A178 & $1.01 \pm 0.24$ & $0.10 \pm 0.04$ & 10.1 & Yes \\
\hline rip61 & -93 & CTCGC-N15-TTCGC-N32-TAAAAA & A211 & $2.32 \pm 1.22$ & $0.17 \pm 0.03$ & 13.6 & Yes \\
\hline rip62 & -540 & TTCGC-N15-TACGG-N31-TATCAT & A67 & $2.28 \pm 0.36$ & $0.17 \pm 0.01$ & 13.4 & Yes \\
\hline rip67 & -117 & TTCGG-N15-TACGC-N31-TATATT & A195 & $24.3 \pm 6.08$ & $0.16 \pm 0.02$ & 152 & Yes \\
\hline rip69 & $\ldots$ & Not found & A280 & $0.35 \pm 0.05$ & $0.18 \pm 0.02$ & 1.9 & No \\
\hline rip70 & $\ldots$ & Not found & $\mathrm{A} 234$ & $0.06 \pm 0.02$ & $0.18 \pm 0.04$ & 0.4 & No \\
\hline rip71 & -98 & TTCGC-N15-TACCG-N33-CAAGGA & A139 & $0.43 \pm 0.07$ & $0.11 \pm 0.02$ & 3.9 & Yes? \\
\hline rip72 & $\ldots$ & Not found & A92 & $1.66 \pm 0.38$ & $0.12 \pm 0.04$ & 13.8 & Yes \\
\hline
\end{tabular}

${ }^{a}$ Position indicates position of the first nucleotide (T) of the first TTCGB motif of a plant-inducible promoter (PIP) box (consensus $5^{\prime}$-TTCGB-N15-TTCGB-3') relative to the start codon of an open reading frame. Conserved nucleotides of a PIP box are shown in bold. $\mathrm{N}$ means the number of spacer nucleotides between the first and second TTCGB motifs of a PIP box or between the second motif of a PIP box and a -10 sequence (consensus $5^{\prime}$-YANNRT-3').

${ }^{\mathrm{b}}$ Adenylate cyclase activity (nmol cAMP per milligram of total soluble protein) is shown as the mean \pm standard deviation of values from three independent experiments.

${ }^{c}$ hrpB-dependent expression. 
type III effector genes in the $R$. solanacearum genome-unsequenced strain RS1000. We screened approximately 105,000 Tn insertion mutants and identified 69 rip genes encoding proteins translocated into plant cells. To date, two Avr-reporterbased functional screening systems for effector genes have been reported. Thirteen effector genes were identified from 75,000 fusions of the AvrRpt $2^{81-255}$ reporter in P. syringae pv. maculicola (Guttman et al. 2002). Similarly, seven effector genes were identified from 14,000 fusions of the AvrBs2 $2^{62-574}$ reporter in X. campestris pv. vesicatoria (Roden et al. 2004). In our Cya-reporter-based screen, 314 positive mutants were isolated by monitoring the increased production of cAMP in inoculated leaves; thus, the frequency of detection of positive mutants per total number of mutants was estimated to be 1/330. In the abovementioned two Avr-reporter-based screens, the frequencies of detecting HR-positive mutants per total number of mutants were 1:3,000 and 1:2,000 (Guttman et al. 2002; Roden et al. 2004). Although the genome size and the number of effector genes would vary among the pathogens, the efficiency of isolating positive mutants using the Cya-based screen is six to nine times higher than those using the Avrbased screens. The high sensitivity of the Cya reporter makes our system a high-throughput system because a pool of 96 insertion mutants could be tested for their translocation activity in one assay in the Cya-based system whereas a pool of only eight insertion mutants could be tested in Avr-based systems.

Most of the rip genes detected by the screen had more than two independent transposon insertions (Tables 1 and 2). This indicates that our screen for rip genes in RS1000 reached a near-saturation level. In a previous work, we identified 34 effector genes in RS1000 (Mukaihara and Tamura 2009). In this study, three genes-namely, hpxl6 (rip18), popB (rip48), and galal (rip53) - could not be detected using the screen (Table 1). The ORF of popB is very small and the expression level of galal is very low (Mukaihara and Tamura 2009). Therefore, it is possible that we have missed some effector genes that are small in size or expressing at very low levels. Nevertheless, we identified 72 Rip proteins in RS1000, and 68 of these are considered to be type III effector proteins, because 4 Rips are probably extracellular components of the Hrp type III secretion apparatus (Table 5). Although genome-based prediction led to the identification of 28 confirmed and 46 candidate effector proteins in $R$. solanacearum GMI1000 (Poueymiro and Genin 2009), in this study, we provide the first experimental validation of a nearcomplete effector repertoire of this pathogen. As far as we know, $R$. solanacearum possesses the largest type III effector repertoire among bacterial pathogens whose repertoire has

Table 4. cAMP levels in plant leaves inoculated with Ralstonia solanacearum $h r p^{+}, \Delta h r p Y$, and $\Delta h p a B$ strains expressing the calmodulin-dependent adenylate cyclase (Cya) fusion protein in the wild-type $h r p B$ background

\begin{tabular}{|c|c|c|c|c|c|c|}
\hline \multirow[b]{2}{*}{ Gene $^{\text {b }}$} & \multirow[b]{2}{*}{ 'cya fusion } & \multicolumn{3}{|c|}{ cAMP level (fold increase) ${ }^{a}$} & \multirow[b]{2}{*}{ Translocation $^{\mathrm{c}}$} & \multirow[b]{2}{*}{ HpaB requirement ${ }^{d}$} \\
\hline & & $h r p^{+}$ & $\Delta h r p Y$ & $\Delta h p a B$ & & \\
\hline None & - & $0.02 \pm 0.004(1.0)$ & $0.02 \pm 0.004$ & $0.02 \pm 0.004(1.0)$ & - & - \\
\hline ripl & A269 & $4.07 \pm 0.45(204)$ & $0.03 \pm 0.002$ & $0.03 \pm 0.002(1.5)$ & Yes & Yes \\
\hline rip2 (hpx11) & hpx11'-'cya & $83.0 \pm 14.9(4,150)$ & $0.06 \pm 0.01(3.0)$ & $0.05 \pm 0.01$ & Yes & Yes \\
\hline rip3 & A40 & $71.7 \pm 5.80(3,585)$ & $0.02 \pm 0.002$ & $0.57 \pm 0.06(28.5)$ & Yes & Yes \\
\hline rip4 & A134 & $16.5 \pm 0.63(825)$ & $0.02 \pm 0.002$ & $0.08 \pm 0.02(4.0)$ & Yes & Yes \\
\hline rip5 (avrA) & A150 & $92.8 \pm 11.0(4,640)$ & $0.05 \pm 0.01$ & $0.06 \pm 0.01(3.0)$ & Yes & Yes \\
\hline rip6 & A256 & $3.20 \pm 0.18$ & $0.02 \pm 0.002$ & $0.02 \pm 0.004$ & Yes & Yes \\
\hline rip7 ( & A69 & $8.71 \pm 1.37(436)$ & $0.04 \pm 0.01(2.0)$ & $0.05 \pm 0.01$ & Yes & Yes \\
\hline rip8 (рорР2-1) & A176 & $86.5 \pm 16.1(4,325)$ & $0.05 \pm 0.01$ & $1.92 \pm 0.37(96.0)$ & Yes & Yes \\
\hline rip9 (popP2-2) & A191 & $3.25 \pm 0.11$ & $0.001 \pm 0.001(0.5)$ & $0.04 \pm 0.006$ & Yes & Yes \\
\hline rip10 & A1 & $83.5 \pm 12.5(4,175)$ & $0.02 \pm 0.001(1.0)$ & $3.41 \pm 0.51(170)$ & Yes & Yes \\
\hline rip11 & A2 & $65.2 \pm 2.19(3,260)$ & $0.04 \pm 0.01(2.0)$ & $1.09 \pm 0.27(54.5)$ & Yes & Yes \\
\hline rip12 (hpx29) & hpx29'-'cya & $98.1 \pm 8.37(4,905)$ & $0.02 \pm 0.004$ & $0.02 \pm 0.01(1.0)$ & Yes & Yes \\
\hline rip13 (hpx13) & hpx $13^{\prime}-{ }^{\prime}$ cya & $54.0 \pm 7.43(2,700)$ & $0.03 \pm 0.01(1.5)$ & $0.04 \pm 0.01(2.0)$ & Yes & Yes \\
\hline rip14 (hpx14) & hpx $14^{\prime}-$ 'cya $^{2}$ & $187 \pm 15.1(9,350)$ & $0.02 \pm 0.002(1.0)$ & $0.55 \pm 0.16(27.5)$ & Yes & Yes \\
\hline rip15 & A 24 & $64.3 \pm 6.20(3,215)$ & $0.02 \pm 0.002(1.0)$ & $0.16 \pm 0.03(8.0)$ & Yes & Yes \\
\hline rip16 & A224 & $78.7 \pm 13.1(3,935)$ & $0.03 \pm 0.002$ & $1.35 \pm 0.25(67.5)$ & Yes & Yes \\
\hline rip17 (hpx15) & hpx15'-'cya & $27.5 \pm 5.44(1,375)$ & $0.02 \pm 0.002(1.0)$ & $0.04 \pm 0.01(2.0)$ & Yes & Yes \\
\hline rip18 (hpx16) & hpx $16^{\prime}-{ }^{\prime}$ cya & $4.53 \pm 0.76(227)$ & $0.03 \pm 0.003$ & $0.03 \pm 0.01(1.5)$ & Yes & Yes \\
\hline rip19 (hpx17) & hpx17'-'cya & $11.3 \pm 3.61(565)$ & $0.07 \pm 0.02$ & $0.05 \pm 0.01(2.5)$ & Yes & Yes \\
\hline rip20 (hpx30) & hp $x 30^{\prime}-^{\prime}$ cya & $40.7 \pm 5.72(2,035)$ & $0.01 \pm 0.002(0.5)$ & $0.11 \pm 0.02(5.5)$ & Yes & Yes \\
\hline rip21 (hpx18) & hpx $18^{\prime}-{ }^{\prime}$ cya & $75.7 \pm 18.2(3,785)$ & $0.03 \pm 0.01$ & $0.18 \pm 0.04(9.0)$ & Yes & Yes \\
\hline rip22 & A189 & $1.68 \pm 0.14$ & $0.02 \pm 0.003(1.0)$ & $0.05 \pm 0.01(1.0)$ & Yes & Yes \\
\hline rip23 (hpx28) & hpx $28^{\prime}-{ }^{\prime} c y a$ & $71.5 \pm 4.90(3,575)$ & $0.02 \pm 0.003$ & $0.05 \pm 0.02(2.5)$ & Yes & Yes \\
\hline rip24 & A279 & $3.93 \pm 0.61(197)$ & $0.04 \pm 0.01$ & $21.8 \pm 5.57(1090)$ & Yes & No \\
\hline rip25 (ripT) & A75 & $88.3 \pm 12.6(4,415)$ & $0.04 \pm 0.01(2.0)$ & $0.21 \pm 0.02(10.5)$ & Yes & Yes \\
\hline rip26 & A15 & $81.2 \pm 14.2(4,060)$ & $0.04 \pm 0.01(2.0)$ & $0.14 \pm 0.03(7.0)$ & Yes & Yes \\
\hline rip27 (hpx37) & hpx37'-'cya & $3.27 \pm 1.20(164)$ & $0.05 \pm 0.01(2.5)$ & $0.04 \pm 0.02(2.0)$ & Yes & Yes \\
\hline rip28 (gala3) & gala3'-'cya & $71.5 \pm 8.70(3,575)$ & $0.03 \pm 0.002(1.5)$ & $0.05 \pm 0.01(2.5)$ & Yes & Yes \\
\hline rip29 $($ hpx31) & hp $x 31^{\prime}-$-cya $^{2}$ & $24.5 \pm 10.2(1,225)$ & $0.03 \pm 0.002(1.5)$ & $0.03 \pm 0.01(1.5)$ & Yes & Yes \\
\hline rip30 & A64 & $49.4 \pm 4.95(2,470)$ & $0.02 \pm 0.002$ & $0.55 \pm 0.03$ & Yes & Yes \\
\hline rip31 & A33 & $52.1 \pm 2.71(2,605)$ & $0.02 \pm 0.003$ & $0.20 \pm 0.04(10.0)$ & Yes & Yes \\
\hline rip32 & A106 & $12.8 \pm 1.91(640)$ & $0.02 \pm 0.001$ & $0.03 \pm 0.006$ & Yes & Yes \\
\hline
\end{tabular}

\footnotetext{
${ }^{a}$ Adenylate cyclase activity (nmol cAMP per milligram of total soluble protein) was measured and is shown as the mean \pm standard deviation of values from three independent experiments. Fold increase indicates the ratio of activity of a strain expressing the Cya fusion protein to that of the parental strain that does not express Cya.

${ }^{\mathrm{b}}$ cAMP levels in the $h r p^{+}$and $\Delta h r p Y$ backgrounds of 34 known rip (Ralstonia protein injected into plant cells) genes were previously reported (Mukaihara and Tamura 2009).

${ }^{\mathrm{c}}$ Hrp-dependent translocation into plant cells.

${ }^{\mathrm{d}} \mathrm{HpaB}$ requirement in translocation.
} 
been analyzed at the genome-wide level. The large repertoire of type III effectors may account for the unusually broad host range that covers more than 200 plant species over several botanical families of $R$. solanacearum.

We previously reported three effector families composed of more than four members: namely, the $\mathrm{Hpx} 4$, Hpx30, and GALA families in RS1000 (Mukaihara and Tamura 2009). In the present study, we identified five additional effector families with amplified gene number: namely, the Hpx8 (Rip68 and Rip72), Rip6 (Rip6 and Rip11), Rip61 (Rip61 and Rip69), XopP (Rip30 and Rip32), and YopJ/AvrRxv (Rip7, Rip8, and Rip9) families (Table 5). Twenty-five effectors belong to the abovementioned eight effector families, and the currently validated $68 R$. solanacearum effectors are found to fall into over 50 families at the protein level.

Among $68 R$. solanacearum effectors, homologues of 45 effectors can be found in other plant- and animal-pathogenic bacteria, although their translocation activities into host cells and their roles in pathogenicity remain unclear (Table 5). This, in turn, indicates that one-third of all the effectors are specific to $R$. solanacearum strains. Eighteen effectors are homologues of type III effector proteins from other plant and animal pathogens, such as AvrBs3, HopD1, HopF2, HopG1, НоpH1, HopQ1, HopR1, HopX1, HopAA1-1, HopAV1, IpaH, XopC, XopP, YopJ/AvrRxv, and YopT/HopC1 (Table 5). Some of the abovementioned effectors have been reported to suppress host defense responses or to stimulate host cellular processes dur- ing infection for the benefit of bacterial proliferation in respective hosts (Shao et al. 2002; Jamir et al. 2004, Kay et al. 2007; Li et al. 2005, Mukherjee et al. 2006, Rohde et al. 2007; Munkvold et al. 2008; Cunnac et al. 2009; Kvitko et al. 2009). It should be examined in a future work whether $R$. solanacearum effectors would have similar activities in plant cells.

It is noteworthy that one-third of the RS1000 effector proteins contain various repeated amino acid sequences (ankyrin repeats, AvrBs3 repeats, leucine-rich repeats, pentatricopeptide repeats, and SKWP repeats) or known enzyme motifs (class III lipase, cyctein proteinase, E3 ubiquitin ligase, nucleoside hydrolase, Nudix hydrolase, Ser/Thr acetyltransferase, and Ser/Thr kinase) (Table 5). It is possible that the targets of these effectors are proteins, lipids, nucleoside derivatives, and DNA or RNA molecules in host plant cells. None of the host factors targeted by $R$. solanacearum effectors have been clarified to date, except PopP2. It has recently been shown that PopP2 physically interacts with Arabidopsis cystein proteinase RD19, an essential host factor for PopP2-triggered RRS1-R-mediated resistance, although the role of RD19 in plant defense responses remains unclear (Bernoux et al. 2008). In addition to the analysis of effector activities in plant cells, the identification of target plant factors would clarify the molecular mechanisms by which effector proteins promote the growth of $R$. solanacearum in host plants.

Among 72 rip genes of RS1000, 27 (37\%) are located on the chromosome and $45(63 \%)$ are on the megaplasmid, indi-

Table 4. (continued from preceding page)

cAMP level (fold increase) ${ }^{\mathrm{a}}$

\begin{tabular}{|c|c|c|c|c|c|c|}
\hline Gene $^{b}$ & 'cya fusion & hrp ${ }^{+}$ & $\Delta h r p Y$ & $\Delta h p a B$ & Translocation $^{c}$ & HpaB requirement ${ }^{\mathrm{d}}$ \\
\hline rip33 (hpx34) & hpx34'-'cya & $13.7 \pm 2.67(685)$ & $0.04 \pm 0.01(2.0)$ & $0.04 \pm 0.01(2.0)$ & Yes & Yes \\
\hline rip34 (hpx25) & hpx $25^{\prime}-^{\prime} c y a$ & $144 \pm 21.3(7,200)$ & $0.04 \pm 0.01(2.0)$ & $0.18 \pm 0.07(9.0)$ & Yes & Yes \\
\hline rip35 & A128 & $49.9 \pm 4.00(2,495)$ & $0.04 \pm 0.01(2.0)$ & $0.03 \pm 0.004(1.5)$ & Yes & Yes \\
\hline rip36 & A216 & $85.9 \pm 9.14(4,295)$ & $0.05 \pm 0.01(2.5)$ & $0.44 \pm 0.10(22.0)$ & Yes & Yes \\
\hline rip37 (hpx20) & hpx $20^{\prime}-^{\prime} c y a$ & $89.5 \pm 8.32(4,475)$ & $0.02 \pm 0.002(1.0)$ & $0.04 \pm 0.01(2.0)$ & Yes & Yes \\
\hline rip38 & A185 & $13.3 \pm 2.67(665)$ & $0.01 \pm 0.001(0.5)$ & $0.03 \pm 0.008(1.5)$ & Yes & Yes \\
\hline rip39 (hpx27) & hpx27'-'cya & $75.2 \pm 5.54(3,760)$ & $0.02 \pm 0.002(1.0)$ & $0.63 \pm 0.16(31.5)$ & Yes & Yes \\
\hline rip40 & A 25 & $87.4 \pm 7.61(4,370)$ & $0.04 \pm 0.01(2.0)$ & $0.90 \pm 0.19(45.0)$ & Yes & Yes \\
\hline rip41 & A160 & $39.1 \pm 7.30(1,955)$ & $0.02 \pm 0.002(1.0)$ & $0.30 \pm 0.02(15.0)$ & Yes & Yes \\
\hline rip42 & A184 & $73.5 \pm 4.38(3,675)$ & $0.01 \pm 0.001(0.5)$ & $0.37 \pm 0.06(18.5)$ & Yes & Yes \\
\hline rip43 (hpx33) & hpx33'-'cya & $21.9 \pm 3.79(1,095)$ & $0.05 \pm 0.02(2.5)$ & $0.07 \pm 0.01(3.5)$ & Yes & Yes \\
\hline rip44 (hpx32) & hpx32'-'cya & $13.6 \pm 2.30(680)$ & $0.04 \pm 0.01(2.0)$ & $0.04 \pm 0.01(2.0)$ & Yes & Yes \\
\hline rip45 (hpx4) & hpx $4^{\prime}-{ }^{\prime}$ cya & $25.7 \pm 2.98(1,285)$ & $0.01 \pm 0.002(0.5)$ & $0.04 \pm 0.01(2.0)$ & Yes & Yes \\
\hline rip46 (hpaZ) & hpaZ'-'cya & $15.0 \pm 1.70(750)$ & $0.04 \pm 0.01(2.0)$ & $45.5 \pm 4.31(2275)$ & Yes & No \\
\hline rip47 (рорС) & pop $C^{\prime}-{ }^{\prime}$ cya & $122 \pm 13.7(6,100)$ & $0.06 \pm 0.01(3.0)$ & $0.03 \pm 0.002(1.5)$ & Yes & Yes \\
\hline rip48 (popB) & pop $B^{\prime}-{ }^{\prime}$ cya & $46.9 \pm 7.08(2,345)$ & $0.16 \pm 0.04(8.0)$ & $207 \pm 17.0(10,350)$ & Yes & No \\
\hline rip49 (рорА) & popA' -' cya & $49.4 \pm 5.20(2,470)$ & $0.25 \pm 0.03(12.5)$ & $275 \pm 32.5(13,750)$ & Yes & No \\
\hline rip50 (hpx2) & hpx $2^{\prime}-{ }^{\prime} c y a$ & $75.3 \pm 3.81(3,765)$ & $0.02 \pm 0.002(1.0)$ & $0.04 \pm 0.01(2.0)$ & Yes & Yes \\
\hline rip51 & A111 & $68.3 \pm 16.7(3,415)$ & $0.02 \pm 0.002(1.0)$ & $0.42 \pm 0.06(21.0)$ & Yes & Yes \\
\hline rip52 ( popF2) & A122 & $2.10 \pm 0.30(105)$ & $0.02 \pm 0.002(1.0)$ & $48.8 \pm 5.40(2,440)$ & Yes & No \\
\hline rip53 (gala1) & galal'-'cya & $4.23 \pm 1.50(212)$ & $0.02 \pm 0.01$ & $0.01 \pm 0.005(0.5)$ & Yes & Yes \\
\hline rip54 (hpx35) & hpx35'-'cya & $16.2 \pm 1.42(810)$ & $0.03 \pm 0.01(1.5)$ & $0.03 \pm 0.01(1.5)$ & Yes & Yes \\
\hline rip55 (hpx21) & hpx $21^{\prime}$-'cya $^{\prime}$ & $14.6 \pm 2.78(730)$ & $0.02 \pm 0.01(1.0)$ & $0.02 \pm 0.01(1.0)$ & Yes & Yes \\
\hline rip56 (hpx10) & hpx $10^{\prime}-^{\prime}$ cya & $57.6 \pm 4.29(2,880)$ & $0.04 \pm 0.001(2.0)$ & $0.07 \pm 0.01(3.5)$ & Yes & Yes \\
\hline rip57 & A94 & $17.4 \pm 2.83(870)$ & $0.02 \pm 0.003(1.0)$ & $0.11 \pm 0.03(5.5)$ & Yes & Yes \\
\hline rip58 (hpx26) & hpx $26^{\prime}-^{\prime} c y a$ & $79.2 \pm 18.9(3,960)$ & $0.03 \pm 0.01$ & $0.02 \pm 0.003$ & Yes & Yes \\
\hline rip59 & A268 & $51.8 \pm 11.8(2,590)$ & $0.02 \pm 0.002(1.0)$ & $0.67 \pm 0.06(33.5)$ & Yes & Yes \\
\hline rip60 & A178 & $19.9 \pm 4.03(995)$ & $0.02 \pm 0.002(1.0)$ & $0.60 \pm 0.04(30.0)$ & Yes & Yes \\
\hline rip61 & A211 & $53.0 \pm 4.17(2,650)$ & $0.01 \pm 0.001(0.5)$ & $0.35 \pm 0.06(17.5)$ & Yes & Yes \\
\hline rip62 & A67 & $1.36 \pm 0.22(68.0)$ & $0.03 \pm 0.004(1.5)$ & $0.03 \pm 0.004(1.5)$ & Yes & Yes \\
\hline rip63 (hpx23) & hpx $23^{\prime}-^{\prime}$ cya & $97.2 \pm 19.2(4,860)$ & $0.02 \pm 0.003(1.0)$ & $0.01 \pm 0.002(0.5)$ & Yes & Yes \\
\hline rip64 (hpx24) & hpx $24^{\prime}-^{\prime}$ cya & $4.24 \pm 1.11(212)$ & $0.03 \pm 0.01$ & $0.01 \pm 0.005(0.5)$ & Yes & Yes \\
\hline rip65 (hpx36) & hpx36'-'cya & $10.8 \pm 1.18(540)$ & $0.05 \pm 0.01(2.5)$ & $0.04 \pm 0.01(2.0)$ & Yes & Yes \\
\hline rip66 (hpx9) & hpx $9^{\prime}-{ }^{\prime} c y a$ & $59.5 \pm 2.40(2,975)$ & $0.01 \pm 0.005(0.5)$ & $0.07 \pm 0.02(3.5)$ & Yes & Yes \\
\hline rip67 & A195 & $27.0 \pm 5.35(1,350)$ & $0.01 \pm 0.002(0.5)$ & $0.44 \pm 0.03(22.0)$ & Yes & Yes \\
\hline rip68 (hpx8) & $h p x 8^{\prime}-' c y a$ & $18.3 \pm 1.87(915)$ & $0.02 \pm 0.003(1.0)$ & $0.04 \pm 0.01(1.0)$ & Yes & Yes \\
\hline rip69 & A 280 & $11.0 \pm 1.86(550)$ & $0.02 \pm 0.002(1.0)$ & $0.10 \pm 0.02(5.0)$ & Yes & Yes \\
\hline rip70 (popF1) & A234 & $4.73 \pm 0.84(237)$ & $0.02 \pm 0.003$ & $22.2 \pm 3.04(1110)$ & Yes & No \\
\hline rip71 & A139 & $29.6 \pm 0.92(1,480)$ & $0.03 \pm 0.002(1.5)$ & $0.29 \pm 0.06(14.5)$ & Yes & Yes \\
\hline rip72 & A92 & $15.7 \pm 2.52(785)$ & $0.02 \pm 0.002(1.0)$ & $0.48 \pm 0.07(24.0)$ & Yes & Yes \\
\hline
\end{tabular}


cating that rip genes of $R$. solanacearum are widely distributed in the genome of this bacterium without forming large gene clusters (Table 5). Comparison of rip genes and their surrounding genes between RS1000 and GMI1000 revealed that the two phylotype I strains are closely related at the DNA level (Table 5). The type III effector repertoires were nearly the same between the two strains, although 11 RS1000 effector genes had mutations, such as frameshift, large internal deletion, and IS insertion. Although their products are translocated into plant cells via the Hrp T3SS (Table 4), these effectors may lose their original activities because they are truncated forms. On the other hand, three rip genes were not found in GMI1000, two of which are deleted or replaced with other probable effector genes (data not shown). Type III effectors recognized as Avr proteins are known to restrict the host range of plant pathogens (Alfano and Collmer 2004; Jones and Dangl 2006). Mutations in the type III effector gene hopQ1-1 of $P$. syringae pv. tomato DC3000 enabled this strain to cause disease in the nonhost Nicotiana benthamiana (Wei et al. 2007). In $R$. solanacearum GMI1000, a combinatorial disruption of two effector genes, $a v r A$ and popPl, enabled this strain to cause disease in N. tabacum (Poueymiro et al. 2009). There- fore, the abovementioned mutations in effector genes might be involved in pathogenic adaptation in certain host plants of this strain by escaping effector recognition.

The Hrp-dependent translocation of 66 effector proteins into plant cells was abolished by the $\triangle h p a B$ mutation (Table 4). Such defects in effector translocation seem to underlie the Hrp-defective phenotype observed in the $\triangle h p a B$ mutant (Mukaihara et al. 2004). $\mathrm{HpaB}$ is a small (17-kDa), acidic (isoelectric point $=4.20)$, and intracellular $(\mathrm{T}$. Mukaihara, $u n$ published data) protein, which is encoded within an hrp gene cluster (Mukaihara et al. 2004). Such characteristics well correspond to those of class IB chaperones in T3SSs (Parsot et al. 2003). It has been shown that $\mathrm{HpaB}$ from $X$. campestris pv. vesicatoria and $X$. oryzae pv. oryzae, which share high homology to that from $R$. solanacearum, controls the secretion of at least four $X$. campestris pv. vesicatoria and $15 X$. oryzae pv. oryzae effectors (Büttner et al. 2004; Furutani et al. 2009). Although the function of $\mathrm{HpaB}$ in $R$. solanacearum should be further investigated in the future, it seems to act as a global effector chaperone for most effector proteins in $R$. solanacearum. The six remaining Rip proteins, including four extracellular components of the Hrp T3SS, were translocated into plant

Table 5. Seventy-two currently identified rip (Ralstonia protein injected into plant cells) genes encoding type III effectors and related proteins in RS1000

\begin{tabular}{|c|c|c|c|}
\hline \multirow[b]{2}{*}{ Type III effector gene } & \multicolumn{2}{|c|}{$\begin{array}{l}\text { Corresponding open reading frame } \\
\text { (\% identity of product) in }\end{array}$} & \multirow[b]{2}{*}{ Comment, type III effector protein, or bacterial species ${ }^{a}$} \\
\hline & GMI1000 & UW551 & \\
\hline \multicolumn{4}{|l|}{ Type III effector gene } \\
\hline $\begin{array}{l}\text { rip1 } \\
\text { rip2 (hpx11) }\end{array}$ & $\mathrm{RSc} 0245(99.3)$ & RRSL_02573 (72.7) & $\begin{array}{l}\text { HopQ1 family, inocine-uridine-preferring nucleoside hydrolase } \\
\text { domain, Aac, Psp, Pst, Xac, Xcc, Xcv, Xoo }\end{array}$ \\
\hline rip3 & $\mathrm{RSc} 0257(50.1)$ & RRSL_01439 (46.5) & Two independent deletions in ankyrin repeat domain \\
\hline rip4 & RSc0321 (98.4) & RRSL_01625 (49.1) & Frameshift mutation, Ser/Thr acetyltransferase domain \\
\hline rip5 (avrA) & RSc0608 (58.8) & RRSL_01581 (73.1) & No known motifs \\
\hline rip6 & RSc0824 (100) & $\ldots$ & Rip6 family, no known motifs \\
\hline rip7 (popP1) & RSc0826 (95.1) & $\ldots$ & $\begin{array}{l}\text { YopJ/AvrRxv family, Ser/Thr acetyltransferase domain, Aac, Pss, Sal, } \\
\text { Xcv, Yer }\end{array}$ \\
\hline rip8 (popP2-1) & RSc0868 (98.6) & $\ldots$ & $\begin{array}{l}\text { YopJ/AvrRxv family, Ser/Thr acetyltransferase domain, Aac, Pss, Sal, } \\
\text { Xcv, Yer }\end{array}$ \\
\hline rip9 (popP2-2) & RSc0868 (94.4) & $\ldots$ & $\begin{array}{l}\text { Frameshift mutation, YopJ/AvrRxv family, Ser/Thr acetyltransferase } \\
\text { domain, Aac, Pss, Sal, Xcv, Yer }\end{array}$ \\
\hline rip10 & $\ldots$ & $\ldots$ & No known motifs, Xcc \\
\hline rip11 & RSc0895 (97.9) & & Rip6 family, no known motifs \\
\hline rip12 (hpx29) & RSc1349 (99.0) & RRSL_01554 (66.6) & IS insertion, IpaH/SspH family, E3 ubiquitin ligase domain, Sal, Shi \\
\hline rip13 (hpx13) & RSc1356 (80.9) & RRSL_01561 (69.7) & Hypervariation, GALA family, type I/GALA LRR domain, Aac, Lp \\
\hline rip14 (hpx14) & $\mathrm{RSc} 1357$ (97.2) & RRSL_01562 (63.1) & GALA family, type I/GALA LRR domain, Aac, Lp \\
\hline rip15 & RSc1386 (98.7) & RRSL_00426 (57.2) & No known motifs, Aac, Xac, Xcc, Xcv \\
\hline rip16 & RSc1475 (99.0) & RRSL_00705 (72.7) & No known motifs, Aac \\
\hline rip17 (hpx15) & RSc1800 (99.0) & RRSL_00532 (56.6) & GALA family, type I/GALA LRR domain, Aac, Lp \\
\hline rip18 (hpx16) & RSc1801 (98.4) & RRSL_00531 (67.0) & GALA family, type I/GALA LRR domain, Aac, Lp \\
\hline rip19 (hpx17) & $\mathrm{RSc} 1815(57.0)$ & $\ldots$ & $\begin{array}{l}\text { Large deletion in central repeat domain, AvrBs3 family, AvrBs3 } \\
\text { repeats, Xac, Xcc, Xcv, Xoo }\end{array}$ \\
\hline rip20 (hpx30) & RSc1839 (96.8) & RRSL_03921 (62.8) & Hpx30 family, SKWP repeat domain, Ml, Psp, Rg, Xac, Xcv, Xoo \\
\hline rip21 (hpx18) & RSc2101 (99.3) & RRSL_01260 (69.0) & No known motifs \\
\hline rip22 & RSc2132 (98.4) & RRSL_04062 (63.7) & IS insertion, no known motifs \\
\hline rip23 (hpx28) & RSc2359 (98.6) & $\ldots$ & No known motifs \\
\hline rip25 (ripT) & RSc3212 (99.7) & $\ldots$ & YopT/HopC1 family, cystein proteinase domain, Ea, Psp, Pst, Yer \\
\hline rip26 & $\operatorname{RSc} 3369(99.1)$ & RRSL_00852 (84.6) & HopX1 family, no known motifs, Pss, Pst, Xac, Xcc, Xcv \\
\hline rip27 (hpx37) & RSc3401 (99.2) & RRSL_04182 (87.7) & Hpx30 family, SKWP repeat domain, Ml, Psp, Rg, Xac, Xcv, Xoo \\
\hline rip28 (gala3) & RSp0028 (96.4) & RRSL_00752 (55.9) & GALA family, type I/GALA LRR domain, Aac, Lp \\
\hline rip29 (hpx31) & RSp0099 (99.4) & RRSL_03418 (78.2) & Hpx4 family, no known motifs, Bg \\
\hline rip30 & RSp0160 (98.9) & RRSL_00041 (81.7) & XopP family, no known motifs, Xac, Xcc, Xcv, Xoo \\
\hline rip31 & RSp0193 (94.9) & $\ldots$ & Pentatricopeptide repeat (PPR) domain \\
\hline rip32 & RSp0215 (97.1) & RRSL_03559 (63.2) & XopP family, no known motifs, Xac, Xcc, Xcv, Xoo \\
\hline rip33 (hpx34) & RSp0296 (98.8) & RRSL_04182 (70.5) & $\begin{array}{r}\text { Hpx30 family, SKWP repeat domain, Ml, Psp, Rg, Xac, Xcv, Xoo } \\
\text { (continued on next pc }\end{array}$ \\
\hline
\end{tabular}

\footnotetext{
${ }^{a}$ Specific comment, similar type III effector protein, or bacterial species containing similar gene. Species abbreviations: Aac, Acidovorax avenae subsp. citrulli; Bg, Burkholderia glumae; Ea, Erwinia amylovora; Lp, Legionella pneumophila; Ml, Mesorhizobium loti; Psp, Pseudomonas syringae pv. phaseolicola; Pss, P. syringae pv. syringae; Pst, P. syringae pv. tomato; Rg, Rickettsiella grylli; Sal, Salmonella sp.; Shi, Shigella sp.; Xac, Xanthomonas axonopodis pv. citri; Xcc, X. campestris pv. campestris; Xcv, X. campestris pv. vesicatoria; Xoo, X. oryzae pv. oryzae; Yer, Yersinia sp.

${ }^{\mathrm{b}}$ Hrp type III secretion system (T3SS) extracellular component gene.
} 
cells via the Hrp T3SS in an HpaB-independent manner, and their levels even increased in the $\triangle h p a B$ background (Table 4). This indicates that HpaB-independent effectors are preferentially translocated into plant cells in the $\triangle h p a B$ background where the translocation of a large number of HpaB-dependent effectors is inefficient. It is interesting that, as in Xanthomonas spp., HpaB is dispensable for the translocation of noneffectors, including the harpin, Hrp pilin, and translocon proteins of $R$. solanacearum.

\section{MATERIALS AND METHODS}

Bacterial strains, media, and culture conditions.

The bacterial strains used in this study are listed in Table 6 . All of the $R$. solanacearum strains are derivatives of RS1085 (Mukaihara et al. 2004), which is a spontaneous $\mathrm{Nal}^{\mathrm{r}} \mathrm{EPS}^{-}$ derivative of the wild-type strain RS1000 (race 1, biovar 4, phylotype I) (Mukaihara et al. 2004). Escherichia coli JM109 (Sambrook et al. 1989) was used for plasmid construction. S17-1 (Simon et al. 1983) was used as a donor for oriT/mob plasmids in conjugation experiments. $R$. solanacearum strains were grown at $28^{\circ} \mathrm{C}$ in all experiments. BG medium (Boucher et al. 1985) was used for standard cultivation. The composition of an hrp-inducing medium has been described (Tamura et al. 2005). E. coli strains were grown in Luria-Bertani medium (Sambrook et al. 1989) at $37^{\circ} \mathrm{C}$. Antibiotics were added to the media as described previously (Mukaihara et al. 2004).

\section{Construction of transposon vector for screening.}

Effector-probing transposon mini-Tn $5^{\prime} c y a$ was constructed from pBSL204 (Alexeyev et al. 1995) and pARO-HA-'Cya (Murata et al. 2006) as follows. pARO-HA-'Cya was linearized with XbaI and inserted into the SpeI site of pBSL204. The resulting plasmid was then digested with $\mathrm{Cla}$ I to exclude the 3.3-kb ClaI fragment containing oriT/mob from pARO-HA'Cya and self-ligated to yield pTNP106. pTNP106 harbors a transposon mini-Tn5'cya, in which the 5'-truncated 'cya gene is associated with the O-end (Fig. 1A).

\section{Transposon insertion and screening}

of $\boldsymbol{R}$. solanacearum rip genes encoding

proteins translocated into plant cells.

$R$. solanacearum $\mathrm{RS} 1085$ and E. coli $\mathrm{S} 17-1$ harboring pTNP106 carrying mini-Tn5'cya were mated on a nitrocellu-

Table 5. (continued from preceding page)

\begin{tabular}{|c|c|c|c|}
\hline \multirow[b]{2}{*}{ Type III effector gene } & \multicolumn{2}{|c|}{$\begin{array}{l}\text { Corresponding open reading frame } \\
(\% \text { identity of product }) \text { in }\end{array}$} & \multirow[b]{2}{*}{ Comment, type III effector protein, or bacterial species ${ }^{\mathbf{a}}$} \\
\hline & GMI1000 & UW551 & \\
\hline rip34 (hpx25) & RSp0304 (97.5) & RRSL_00947 (62.8) & HopD1 family, no known motifs, Aac, Psp, Pst, Xcv \\
\hline rip35 & RSp0323 (98.7) & RRSL_00926 (83.2) & HopG1 family, no known motifs, Aac, Psp, Pst, Xac, Xcc \\
\hline rip36 & RSp0572 (100) & $\ldots$ & HopH1 family, no known motifs, Aac, Pss, Pst, Xcc, Xcv, Xoo \\
\hline rip37 (hpx20) & RSp0672 (97.8) & RRSL_02264 (69.0) & GALA family, type I/GALA LRR domain, Aac, Lp \\
\hline rip38 & $\ldots$ & RRSL_02221 (77.2) & Class III lipase domain, Aac, Xac, Xcv, Xoo \\
\hline rip39 (hpx27) & RSp0732 (99.5) & RRSL_02213 (85.8) & HopAV1 family, no known motifs, Psp \\
\hline rip40 & RSp0822 (96.3) & $\ldots$ & HopF2 family, no known motifs, Aac, Psp, Pst \\
\hline rip41 & RSp0838 (99.0) & RRSL_01021 (79.2) & No known motifs, $\mathrm{Bg}$ \\
\hline rip42 & RSp0839 (88.1) & RRSL_01019 (29.7) & No known motifs \\
\hline rip43 (hpx33) & RSp0845 (99.5) & RRSL_01013 (71.3) & No known motifs \\
\hline rip44 (hpx32) & RSp0846 (98.5) & $\ldots$ & Hpx4 family, no known motifs, Bg \\
\hline rip45 (hpx4) & RSp0847 (98.3) & $\ldots$ & Hpx4 family, no known motifs, Bg \\
\hline rip47 (popC) & RSp0875 (99.7) & RRSL_02441 (50.2) & Type II LRR domain, Xcv \\
\hline rip48 (popB) & RSp0876 (98.9) & RRSL_02442 (69.9) & No known motifs \\
\hline rip49 (рорА) & RSp0877 (94.2) & RRSL_02443 (60.8) & No known motifs \\
\hline rip50 (hpx2) & RSp0879 (98.3) & RRSL_03105 (51.1) & No known motifs \\
\hline rip51 & RSp0885 (98.3) & RRSL_03113 (68.2) & No known motifs, Aac \\
\hline rip53 (galal) & RSp0914 (80.1) & $\ldots$ & $\begin{array}{l}\text { Two independent deletions in LRR, GALA family, type I/GALA LRR } \\
\text { domain, Aac, Lp }\end{array}$ \\
\hline rip54 (hpx35) & RSp0930 (98.6) & RRSL_00237 (78.3) & Hpx30 family, SKWP repeat domain, Ml, Psp, Rg, Xac, Xcv, Xoo \\
\hline rip55 (hpx21) & RSp1022 (96.2) & RRSL_01066 (59.7) & No known motifs, Aac \\
\hline rip56 $($ hpx10) & RSp1024 (98.2) & RRSL_01071 (77.9) & Hpx4 family, no known motifs, Bg \\
\hline rip57 & RSp1031 (98.6) & RRSL_00271 (49.3) & No known motifs \\
\hline rip58 (hpx26) & RSp1130 (97.3) & RRSL_04736 (76.8) & Nudix hydrolase domain \\
\hline rip59 & $\ldots$ & RRSL_04660 (74.8) & No known motifs \\
\hline rip60 & RSp1218 (99.4), RSp1215 (98.7) & RRSL_04655 (78.3) & $\begin{array}{l}\text { IS insertion in GMI1000, Ser/Thr kinase domain, ankyrin repeat } \\
\text { domain }\end{array}$ \\
\hline rip61 & RSp1236 (98.2) & RRSL_01136 (63.8) & Rip61 family, no known motifs \\
\hline rip62 & RSp1239 (98.8) & RRSL_03371 (71.8) & XopC family, no known motifs, Aac, Xac, Xcc, Xcv, Xoo \\
\hline rip63 (hpx23) & RSp1277 (99.4) & RRSL_02855 (75.1) & HopAA1-1 family, no known motifs, Pss, Pst \\
\hline rip64 (hpx24) & RSp1281 (99.2) & RRSL_03375 (79.8) & HopR1 family, no known motifs, Psp, Pst, Xcc \\
\hline rip65 (hpx36) & RSp1374 (98.9) & $\ldots$ & Hpx30 family, SKWP repeat domain, Ml, Psp, Rg, Xac, Xcv, Xoo \\
\hline rip66 $($ hpx 9$)$ & RSp1384 (99.0) & RRSL_00571 (51.2) & No known motifs \\
\hline rip67 & RSp1388 (94.1) & RRSL_00576 (42.2) & IS insertion, no known motifs \\
\hline rip68 $($ hpx8) & RSp1460 (98.7) & RRSL_02518 (39.6) & Hpx8 family, no known motifs, Aac, Xac, Xcv, Xoo \\
\hline rip69 & RSp1475 (96.2) & $\ldots$ & Rip61 family, no known motifs \\
\hline rip71 & RSp1582 (90.5) & $\ldots$ & Frameshift mutation, no known motifs, Lp \\
\hline rip72 & RSp1601 (97.5) & RRSL_02518 (61.8) & Hpx8 family, no known motifs, Aac, Xac, Xcv, Xoo \\
\hline \multicolumn{4}{|l|}{ Hrp T3SS } \\
\hline rip24 & RSc2775 (99.5) & RRSL_02682 (80.1) & $\begin{array}{l}\text { HrpW family, harpin-like protein, pectate lyase domain, Aac, Ea, Pss, } \\
\text { Xac, Xcc }\end{array}$ \\
\hline rip46 (hpaZ) & RSp0854 (97.3) & RRSL_00507 (62.7) & Similar to Hrp pilin protein HrpY \\
\hline rip52 (popF2) & RSp0900 (98.8) & RRSL_04777 (81.4) & HrpF/XopX family, T3SS translocator, M1, Xac, Xcc, Xcv, Xoo \\
\hline $\operatorname{rip} 70($ popF1) & RSp1555 (99.0) & RRSL_04777 (78.2) & HrpF/XopX family, T3SS translocator, Ml, Xac, Xcc, Xcv, Xoo \\
\hline
\end{tabular}


Table 6. Bacterial strains

\begin{tabular}{|c|c|c|}
\hline Strain & Description & Reference \\
\hline \multicolumn{3}{|c|}{ Ralstonia solanacearum } \\
\hline RS1085 & $\mathrm{Nal}^{\mathrm{r}} \Delta e p s P$ & Mukaihara et al. 2004 \\
\hline RS1204 & RS1085 $\Delta(h r p B-h r c T)$ & Murata et al. 2006 \\
\hline RS1212 & RS1085 $\Delta h p a B$ & Mukaihara et al. 2004 \\
\hline RS1239 & RS1085 RSc2836::mini-Tn5hrpB (constitutively expressing $h r p B\left[h r p B^{\mathrm{c}}\right]$ ) & Tamura et al. 2005 \\
\hline RS1254 & RS1085 $\Delta h r p Y$ & Mukaihara et al. 2004 \\
\hline \multicolumn{3}{|c|}{ Escherichia coli } \\
\hline JM109 & recA1 supE44 endA1 hsdR17 gyrA96 relA1 $\Delta\left(\right.$ lac-proAB) $\mathrm{F}^{\prime}\left(\right.$ traD36 proAB ${ }^{+}$lacI ${ }^{q}$ lacZ $\left.\Delta \mathrm{M} 15\right)$ & Sambrook et al. 1989 \\
\hline S17-1 & thi pro hsdR $h s d M^{+}$recA (chr::RP4-2-Tc::Mu-Km::Tn7) & Simon et al. 1983 \\
\hline
\end{tabular}

lose membrane filter on $\mathrm{BG}$ plates at $28^{\circ} \mathrm{C}$ overnight. Samples were spread and incubated on BG plates containing kanamycin $(20 \mu \mathrm{g} / \mathrm{ml})$ and nalidixic acid $(30 \mu \mathrm{g} / \mathrm{ml})$ at $28^{\circ} \mathrm{C}$. Antibiotic-resistant transconjugants appeared after 3 days of incubation. Single colonies were inoculated into 96-well deep plates containing $0.5 \mathrm{ml}$ of $\mathrm{BG}$ medium containing nalidixic acid $(10 \mu \mathrm{g} / \mathrm{ml})$ using toothpicks. To avoid the isolation of siblings, only 96 transconjugants were isolated from a selection plate of each mating mixture. The 96-well deep plates were incubated at $28^{\circ} \mathrm{C}$ overnight with agitation at $1,300 \mathrm{rpm}$ using TAITEC BioShaker (TAITEC, Saitama, Japan). To preserve the original plates, $50 \mu \mathrm{l}$ of an overnight culture in each well was transferred into a new 96-well microplate and mixed with an equal amount of $30 \%$ glycerol (final concentration, $15 \%$ glycerol) for storing at $-80^{\circ} \mathrm{C}$. For screening, a set of overnight cultures of 96 transconjugants from one plate was combined as a pool, centrifuged, washed once with distilled water (DW) and resuspended in DW at an optical density at $600 \mathrm{~nm}=0.5$ (approximately $\left.5 \times 10^{8} \mathrm{CFU} / \mathrm{ml}\right)$. The mixed bacterial suspension was inoculated into fully expanded leaves of 6-week-old susceptible eggplants using a needleless syringe, and the inoculated plants were kept in a greenhouse at $28^{\circ} \mathrm{C}$. Two leaf disks $\left(0.8 \mathrm{~cm}^{2}\right.$ each $)$ were taken $15 \mathrm{~h}$ after inoculation, frozen in liquid nitrogen, and kept at $-80^{\circ} \mathrm{C}$. Extracts of plant samples were prepared as previously described (Murata et al. 2006). Using an aliquot of a 10- $\mu$ l plant extract, cAMP level was measured using a cAMP enzyme immunoassay kit (Biotrack; GE healthcare, Buckinghamshire, U.K.). Pools that showed a marked increase in the cAMP level (more than $50 \mathrm{fmol} /$ well) in the inoculated leaves compared with other samples were chosen as positive pools. Under the experimental condition that we used, 70 to $75 \%$ of pools showed a cAMP level below the detection limit (less than 12.5 $\mathrm{fmol} /$ well). $R$. solanacearum mutants included in the positive pool were divided into several subgroups, and the plant assay was repeated until a single positive mutant was specified. We did not choose pools that showed a small increase in the cAMP level (12.5 to $50 \mathrm{fmol} /$ well) because no positive mutant was isolated from these pools in the beginning of this screening using approximately 24,000 mutants.

\section{Cloning and sequencing of rip genes.}

Genomic DNA from mini-Tn5'cya insertion mutants purified with a Genomic DNA Extraction Kit (Qiagen, Valencia, CA, U.S.A.) was digested and self-ligated for the transformation of JM109. Because the transposon contains the ColE1-type origin (Fig. 1A), when genomic DNA was digested with an appropriate restriction enzyme, the surrounding region of the transposon can be rescued as a plasmid in E. coli. ApaI, ClaI, KpnI, or MluI was used to clone the upstream region of the transposon, and BamHI, NotI, or SmaI was used for the downstream rescue. For sequencing the Tn insertion sites, the primer P1041 (5'-G AGTACGGCTGCGGGGATG-3') was used for O-end junctions and the primer P2043 (5'-AACGGATTCACCACTCCA AGA-3') for I-end junctions.
Construction of $\boldsymbol{R}$. solanacearum mutants expressing Cya fusion protein and adenylate cyclase activity assay.

For the rip genes newly isolated in this study, a genomic DNA $(2 \mu \mathrm{g})$ from $R$. solanacearum Tn insertion mutants was electroporated into the strain RS1204 ( $\Delta h r p B), \mathrm{RS} 1212$ $(\triangle h p a B)$, or RS1254 $(\Delta h r p Y)$ under the conditions previously described (Mukaihara et al. 2004) and selected for the $\mathrm{Kan}^{\mathrm{r}}$ recombinants. An $h r p B^{\mathrm{c}}$ mutant was constructed for each $\Delta h r p B$ strain by electroporating the genomic DNA of the $h r p B^{\mathrm{c}}$ strain RS1239 (Tamura et al. 2005) and selecting the gentamycinresistant recombinants. For the rip genes previously identified, a plasmid integration system was used to construct the $\Delta h p a B$ mutant expressing the Cya fusion protein as described previously (Mukaihara and Tamura 2009). The protocol of in vitro or in planta adenylate cyclase activity assay and the procedure of cAMP extraction from each sample have been described (Murata et al. 2006).

\section{ACKNOWLEDGMENT}

This work was supported by a Grant-in-Aid for Scientific Research (No. 20580050) to T. Mukaihara from the Ministry of Education, Culture, Sports, Science and Technology, Japan.

\section{LITERATURE CITED}

Alexeyev, M. F., Shokolenko, I. N., and Croughan, T. P. 1995. New miniTn5 derivatives for insertion mutagenesis and genetic engineering in gram-negative bacteria. Can. J. Microbiol. 41:1053-1055.

Alfano, J. R., and Collmer, A. 1997. The type III (Hrp) secretion pathway of plant pathogenic bacteria: Trafficking harpins, Avr proteins and death. J. Bacteriol. 179:5655-5662.

Alfano, J. R., and Collmer, A. 2004. Type III secretion system effector proteins: Double agents in bacterial disease and plant defense. Annu. Rev. Phytopathol. 42:385-414.

Almeida, N. F., Shuangchun, Y., Lindeberg, M., Studholme, D. J., Schneider, D. J., Condon, B., Liu, H., Viana, C. J., Warren, A., Evans, C., Kemen, E., MacLean, D., Angot, A., Martin, G. B., Jones, J. D., Collmer, A., Setubal, J. C., and Vinatzer, B. A. 2009. A draft genome sequence of Pseudomonas syringae pv. tomato T1 reveals a type III effector repertoire significantly divergent from that of Pseudomonas syringae pv. tomato DC3000. Mol. Plant-Microbe Interact. 22:52-62.

Bernoux, M., Timmers, T., Jauneau, A., Briere, C., de Wit, P. J., Marco, Y., and Deslandes, L. 2008. RD19, an Arabidopsis cystein proteinase required for RRS1-R-mediated resistance, is relocalized to the nucleus by the Ralstonia solanacearum PopP2 effector. Plant Cell 20:22522264

Boucher, C. A., Barberis, P. A., Trigalet, A. P., and Demery, D. 1985. Transposon mutagenesis of Pseudomonas solanacearum: Isolation of Tn5-induced avirulent mutants. J. Gen. Microbiol. 131:2449-2457.

Boucher, C. A., Van Gijsegem, F., Barberies, P. A., Arlat, M., and Zischek, C. 1987. Pseudomonas solanacearum genes controlling both pathogenicity on tomato and hypersensitivity on tobacco are clustered. J. Bacteriol. 169:5626-5633.

Büttner, D., Gürlebeck, D., Noël, L. D., and Bonas, U. 2004. HpaB from Xanthomonas campestris pv. vesicatoria acts as an exit control protein in type III-dependent protein secretion. Mol. Microbiol. 54:755-768.

Chang, J. H., Urbach, J. M., Law, T. F., Arnold, L. W., Hu, A., Gombar, S., Grant, S. R., Ausbel, F. M., and Dangle, J. L. 2005. A high-throughput, near saturating screen for type III effector genes from Pseudomonas syringae. Proc. Natl. Acad. Sci. U.S.A. 102:2549-2554. 
Charkowski, A. O., Alfano, J. R., Preston, G., Yuan, J., He, S. Y., and Collmer, A. 1998. The Pseudomonas syringae pv. tomato HrpW protein has domains similar to harpins and pectate lyases and can elicit the plant hypersensitive response and bind to pectate. J. Bacteriol. 180:5211-5217.

Cornelis, G. R., and Van Gijsegem, F. 2000. Assembly and function of type III secretory systems. Annu. Rev. Microbiol. 54:735-774.

Cunnac, S., Occhialini, A., Barberis, P., Boucher, C., and Gennin, S. 2004 Inventory and functional analysis of the large Hrp regulon in Ralstonia solanacearum: Identification of novel effector proteins translocated to plant host cells through the type III secretion system. Mol. Microbiol. 23:115-128.

Cunnac, S., Lindeberg, M., and Collmer, A. 2009 Pseudomonas syringae type III secretion system effectors: Repertoires in search of functions. Curr. Opin. Microbiol. 12:53-60.

Deslandes, L., Olivier, J., Peeters, N., Feng, D., Khounlotham, M., Boucher, C., Somssich, I., Genin, S., and Marco, Y. 2003. Physical interaction between RRS1-R, a protein conferring resistance to bacterial wilt, and PopP2, a type III effector targeted to the plant nucleus. Proc. Natl. Acad. Sci. U.S.A. 100:8024-8029.

Ferreira, A. O., Myers, C. R., Gordon, J. S., Martin, G. B., Vencato, M., Collmer, A., Wehling, M. D., Alfano, J. R., Moreno-Hagelsieb, G., Lamboy, W. F., DeClerck, G., Schneider, D. J., and Cartinhour, S. W. 2006. Whole-genome expression profiling defines the HrpL regulon of Pseudomonas syringae pv. tomato DC3000, allows de novo reconstruction of the Hrp cis element, and identifies novel co-regulated genes. Mol. Plant-Microbe Interact. 19:1167-1179.

Fouts, D. E., Abramovitch, R. B., Alfano, J. R., Baldo, A. M., Buell, C. R., Cartinhour, S., Chatterjee, A. K., D’Ascenzo, M., Gwinn, M. L., Lazarowitz, S. G., Lin, N. C., Martin, G. B., Rehm, A. H., Schneider, D. J., van Dijk, K., Tang, X., and Collmer, A. 2002. Genomewide identification of Pseudomonas syringae pv. tomato DC3000 promoters controlled by the HrpL alternative sigma factor. Proc. Natl. Acad. Sci. U.S.A. 99:2275-2280

Furutani, A., Takaoka, M., Sanada, H., Noguchi, Y., Oku, T., Tsuno, K., Ochiai, H., and Tsuge, S. 2009. Identification of novel type III secretion effectors in Xanthomonas oryzae pv. oryzae. Mol. Plant-Microbe Interact. 22:96-106.

Gabriel, D. W., Allen, C., Schell, M., Denny, T. P., Greenberg, J. T., Duan, Y. P., Flores-Cruz, Z., Huang, Q., Clifford, J. M., Presting, G., González, E. T., Reddy, J., Elphinstone, J., Swanson, J., Yao, J., Mulholland, V., Liu, L., Farmerie, W., Patnaikuni, M., Balogh, B., Norman, D., Alvarez, A., Castillo, J. A., Jones, J., Saddler, G., Walunas, T., Zhukov, A., and Mikhailova, N. 2006. Identification of open reading frames unique to a select agent: Ralstonia solanacearum race 3 biovar 2. Mol. PlantMicrobe Interact. 19:69-79.

Galán, J. E., and Wolf-Watz, H. 2006. Protein delivery into eukaryotic cells by type III secretion machines. Nature 444:567-573.

Genin, S., Gough, C. L., Zischek, C., and Boucher, C. A. 1992. Evidence that the $h r p B$ gene encodes a positive regulator of pathogenicity genes from Pseudomonas solanacearum. Mol. Microbiol. 6:3065-3076.

Gohre, V., and Robatzek, S. 2008. Breaking the barriers: Microbial effector molecules subvert plant immunity. Annu. Rev. Phytopathol. 46:189215

Guttman, D. S., Vinatzer, B. A., Sarkar, S. F., Ranall, M. V., Kettler, G., and Greenberg, J. T. 2002. A functional screen for the type III (Hrp) secretome of the plant pathogen Pseudomonas syringae. Science 295:1722-1726.

Hayward, A. C. 1991. Biology and epidemiology of bacterial wilt caused by Pseudomonas solanacearum. Annu. Rev. Phytopathol. 29:65-87.

Jamir, Y., Guo, M., Oh, H.-S., Petnicki-Ocwieja, T., Chen, S., Tang, X., Dickman, M. B., Collmer, A., and Alfano, J. R. 2004. Identification of Pseudomonas syringae type III effectors that can suppress programmed cell death in plants and yeast. Plant J. 37:554-565.

Jones, J. D. G., and Dangl, J. L. 2006. The plant immune system. Nature 444:323-329

Kay, S., Hahn, S., Marois, E., Hause, G., and Bonas, U. 2007. A bacterial effector acts as a plant transcription factor and induces a cell size regulator. Science 318:648-651.

Kim, J. F., and Beer, S. V. 1998. HrpW of Erwinia amylovora, a new harpin that contains a domain homologous to pectate lyases of a distinct class. J. Bacteriol. 180:5203-10.

Kvitko, B. H., Park, D. H., Velásquez, A. C., Wei, C. F., Russell, A. B., Martin, G. B., Schneider, D.J., and Collmer A. 2009. Deletions in the repertoire of Pseudomonas syringae pv. tomato DC3000 type III secretion effector genes reveal functional overlap among effectors. PLoS Pathog 5:e1000388. doi:10.1371/journal.ppat.1000388. Published online.

Lavie, M., Shillington, E., Eguiluz, C., Grimsley, N., and Boucher, C. 2002. PopP1, a new member of YopJ/AvrRxv family of type III effector proteins, acts as a host-specificity factor and modulates aggressiveness of Ralstonia solanacearum. Mol. Plant-Microbe Interact. 15:10581068.

Li, X., Lin, H., Zhang, W., Zou, Y., Zhang, J., Tang, X., and Zhou, J.-M. 2005. Flagellin induces innate immunity in nonhost interactions that is suppressed by Pseudomonas syringae effectors. Proc. Natl. Acad. Sci. U.S.A. 102:12990-12995.

Lindeberg, M., Cartinhour, S., Myeres, C. R., Schechter, L. M., Schneider, D. J., and Collmer, A. 2006. Closing the circle on the discovery of genes encoding Hrp regulon members and type III secretion system effectors in the genomes of three model Pseudomonas syringae strains. Mol. Plant-Microbe Interact. 19:1151-1158.

Meyer, D., Cunnac, S., Guéneron, M., Declercq, C., Van Gijsegem, F., Lauber, E., Boucher, C., and Arlat, M. 2006. PopF1 and PopF2, two proteins secreted by the type III protein secretion system of Ralstonia solanacearum, are translocators belonging to the HrpF/NopX family. J. Bacteriol. 188:4903-4917.

Mota, L. J., and Cornelis, G. R. 2005. The bacterial injection kit: Type III secretion systems. Ann. Med. 37:234-249.

Mudgett, B. M. 2005. New insights to the function of phytopathogenic bacterial type III effectors in plants. Annu. Rev. Plant Biol. 56:509-531.

Mukaihara, T., and Tamura, N. 2009. Identification of novel Ralstonia solanacearum type III effector proteins through translocation analysis of $h r p B$-regulated gene products. Microbiology 155:2235-2244.

Mukaihara, T., Tamura, N., Murata, Y., and Iwabuchi, M. 2004. Genetic screening of Hrp type III-related pathogenicity genes controlled by the HrpB transcriptional activator in Ralstonia solanacearum. Mol. Microbiol. 54:863-875

Mukherjee, S., Keitany, G., Li, Y., Wang, Y., Ball, H. L., Goldsmith, E. J., and Orth, K. 2006. Yersinia YopJ acetylates and inhibits kinase activation by blocking phosphorylation. Science 312:1211-1214.

Munkvold, K. R., Martin, M. E., Bronstein, P. A., and Collmer, A. 2008. A survey of the Pseudomonas syringae pv. tomato DC3000 type III secretion system effector repertoire reveals several effectors that are deleterious when expressed in Saccharomyces cerevisiae. Mol. Plant-Microbe Interact. 21:490-502.

Murata, Y., Tamura, N., and Mukaihara, T. 2006. Mutations in the $\operatorname{lrpE}$ gene of Ralstonia solanacearum affect Hrp pili production and virulence. Mol. Plant-Microbe Interact. 19:884-895.

Noël, L., Thieme, F., Nennstiel, D., and Bonas, U. 2001. cDNA-AFLP analysis unravels a genome-wide $h r p G$-regulon in the plant pathogen Xanthomonas campestris pv. vesicatoria. Mol. Microbiol. 41:1271-1281.

Occhialini, A., Cunnac, S., Reymond, N., Genin, S., and Boucher, C. 2005 Genome-wide analysis of gene expression in Ralstonia solanacearum reveals that the $h r p B$ gene acts as a regulatory switch controlling multiple virulence pathways. Mol. Plant-Microbe Interact. 18:938-949.

Parsot, C., Hamiaux, C., and Page, A. L. 2003. The various and varying roles of specific chaperones in type III secretion systems. Curr. Opin. Microbiol. 6:7-14.

Petnicki-Ocwieja, T., Schneider, D. J., Tam, V.C., Chancey, S. T., Shan, L. T., Jamir, Y., Schechter, L. M., Janes, M. D., Buell, C. R., Tang, X., Collmer, A., and Alfano, J. R. 2002. Genomewide identification of proteins secreted by the Hrp type III protein secretion system of Pseudomonas syringae pv. tomato DC3000. Proc. Natl. Acad. Sci. U.S.A 99:7652-7657.

Poueymiro, M., and Genin, S. 2009. Secreted proteins from Ralstonia solanacearum: A hundred tricks to kill a plant. Curr. Opin. Microbiol. 12:44-52.

Poueymiro, M., Cunnac, S., Barberis, P., Deslandes, L., Peeters, N., CazaleNoel, A.-C., Boucher, C., and Genin, S. 2009. Two type III secretion system effectors from Ralstonia solanacearum GMI1000 determine hostrange specificity on tobacco. Mol. Plant-Microbe Interact. 22:538-550.

Roden, J. A., Belt, B., Ross, J. B., Tachibana, T., Vargas, J., and Mudgett, M. B. 2004. A genetic screen to isolate type III effectors translocated into pepper cells during Xanthomonas infection. Proc. Natl. Acad. Sci. U.S.A. 101:16624-16629.

Rohde, J. R., Breitkreutz, A., Chenal, A., Sansonetti, P. J., and Parsot, C. 2007. Type III secretion effectors of the IpaH family are E3 ubiquitin ligases. Cell Host Microbe 1:77-83.

Salanoubat, M., Genin, S., Artiguenave, F., Gouzy, J., Mangenot, S., Arlat, M., Billault, A., Brottier, P., Camus, J. C., Cattolico, L., Chandler, M., Choisne, N., Claudel-Renard, C., Cunnac, S., Demange, N., Gaspin, C., Lavie, M., Moisan, A., Robert, C., Saurin, W., Schiex, T., Siguier, P. Thebault, P., Whalen, M., Wickner, P., Levy, M., Weissenbach, J., and Boucher, C. A. 2002. Genome sequence of the plant pathogen Ralstonia solanacearum. Nature 415:497-502.

Sambrook, J., Fritsch, E. F., and Maniatis, T. 1989. Molecular Cloning: A Laboratory Manual, 2nd ed. Cold Spring Harbor Laboratory, Cold Spring Harbor, NY, U.S.A

Schechter, L. M., Roberts, K. A., Jamir, Y., Alfano, J. R., and Collmer, A. 
2004. Pseudomonas syringae type III secretion system targeting signals and novel effectors studied with a Cya translocation reporter. J. Bacteriol. 186:543-555.

Schechter, L. M., Vencato, M., Jordan, K. L., Schneider, S. E., Schneider, D. J., and Collmer, A. 2006. Multiple approaches to a complete inventory of Pseudomonas syringae pv. tomato DC3000 type III secretion system effector proteins. Mol. Plant-Microbe Interact. 19:1180-1192.

Schell, M. A. 2000. Control of virulence and pathogenicity genes of Ralstonia solanacearum by an elaborate sensory network. Annu. Rev. Phytopathol. 38:263-292.

Shao, F., Merritt, P., Bao, Z., Innes, R., and Dixon, J. 2002. A Yersinia effector and a Pseudomonas avirulence protein define a family of cysteine proteases functioning in bacterial pathogenesis. Cell 109:575-588

Simon, R., Priefer, U., and Pühler, A. 1983. A broad host range mobilization system for in vivo genetic engineering: Transposon mutagenesis in gram negative bacteria. Bio/Technology 1:784-791.

Sory, M. P., and Cornelis, G. R. 1994. Translocation of a hybrid YopE-adenylate cyclase from Yersinia enterocolitica into HeLa cells. Mol. Microbiol. 14:583-594.

Spiteri, A., Viratelle, O. M., Raymond, P., Rancillac, M., Labouesse, J., and Pradet, A. 1989. Artefactual origins of cyclic AMP in higher plant tissues. Plant Physiol. 91:624-628.
Tamura, N., Murata, Y., and Mukaihara, T. 2005. Isolation of Ralstonia solanacearum $h r p B$ constitutive mutants and secretion analysis of $h r p B$ regulated gene products that share homology with known type III effectors and enzymes. Microbiology 151:2873-2884.

Van Gijsegem, F., Vasse, J., Camus, J.C., Marenda, M., and Boucher, C. 2000. Ralstonia solanacearum produces Hrp-dependent pili that are required for PopA secretion but not for attachment of bacteria to plant cells. Mol. Microbiol. 36:249-260.

Vinatzer, B. A., Teitzel, G. M., Lee, M. W., Jelenska, J., Hotton, S., Fairfax, K., Jenrette, J., and Greenberg, J. T. 2006. The type III effector repertoire of Pseudomonas syringae pv. syringae B728a and its role in survival and disease on host and non-host plants. Mol. Microbiol. 62:26-44.

Wei, C. F., Kvitko, B. H., Shimizu, R., Crabill, E., Alfano, J. R., Lin, N. C., Martin, G. B., Huang, H. C., and Collmer, A. 2007. A Pseudomonas syringae pv. tomato DC3000 mutant lacking the type III effector HopQ1-1 is able to cause disease in the model plant Nicotiana benthamiana. Plant J. 51:32-46.

Zwiesler-Vollick, J., Plovanich-Jones, A., Nomura, K., Bandyopadhyay, S., Joardar, V., Kunkel, B. N., and He, S. Y. 2002. Identification of novel hrp-regulated genes through functional genomic analysis of the Pseudomonas syringae pv. tomato DC3000 genome. Mol. Microbiol. 45:12071218 